University of Chicago Law School

Chicago Unbound

Journal Articles

Faculty Scholarship

1996

\title{
Economics of the Law of Criminal Attempts: A Victim-Centered Perspective
}

Omri Ben-Shahar

Follow this and additional works at: https://chicagounbound.uchicago.edu/journal_articles

Part of the Law Commons

\section{Recommended Citation}

Omri Ben-Shahar \& Alon Harel, "Economics of the Law of Criminal Attempts: A Victim-Centered Perspective ," 145 University of Pennsylvania Law Review 299 (1996).

This Article is brought to you for free and open access by the Faculty Scholarship at Chicago Unbound. It has been accepted for inclusion in Journal Articles by an authorized administrator of Chicago Unbound. For more information, please contact unbound@law.uchicago.edu. 
THE ECONOMICS OF THE LAW OF GRIMINAL ATTEMPTS:

A VICTIM-GENTERED PERSPECTIVE

\section{OMRI BEN-SHAHAR $†$ \& ALON HAREL $\dagger$}

\section{INTRODUCTION}

A criminal act ordinarily involves two parties: a perpetrator and a victim. Criminal law scholarship in general, and economic analysis in particular, traditionally endorse a perpetrator-centered perspective. Under this perspective, all factors relevant to the design of criminal norms emanate from attributes of actual or potential perpetrators of crime. Justifications for punishment and the severity of punishment are based exclusively upon characteristics of the criminal's behavior or mental state. The victim's role is confined to the suffering of harm, while his conduct prior to the crime is generally of no normative concern. ${ }^{1}$

This Article challenges the perpetrator-centered perspective and proposes a complementary perspective-a victim-centered one. The Article argues that the perpetrator-centered perspective is too narrow because it overlooks the important role that victims have in pre-crime settings. In particular, it neglects the victims' role in taking precautions and protecting themselves against crime, a neglect which leads to a socially undesirable investment in precautionary measures. ${ }^{2}$ By approaching criminal law from a victim-centered per-

† Assistant Professor of Law and Economics, Tel-Aviv University.

it Senior Lecturer of Law, Hebrew University, Israel. We are grateful to Scott Altman, Sarah Clarke Ben-Shahar, Miriam Gur-Aryeh, Yoram HaLevy, Marty Levine, Mike Otsuka, Ed Rock, Ron Shapira, Max Stearns and Eric Talley, as well as workshop participants at the University of Pennsylvania Law School, the 1996 American Law and Economics Association meeting, the 1996 European Law and Economics Association meeting and Tel-Aviv University School of Law for helpful comments on previous drafts. The Olin Program in Law and Economics at Harvard Law School and the Taubenschlag Criminal Law Institute at Tel-Aviv University provided financial support.

${ }^{1}$ For introductory presentations of the economic analysis of the criminal law that exemplify the perpetrator-centered perspective, see generally ROBERT COOTER \& THOMAS Ulen, LAW AND ECONOMICS 506-84 (1988); A. MTTCHELl POLINSKY, AN INTRODUCTION TO LAW AND ECONOMICS 75-86 (2d ed. 1989); RICHARD A. POSNER, ECONOMIC ANALYSIS OF LAW 223-47 (4th ed. 1992).

${ }^{2}$ Previous studies have examined the victims' decisionmaking process in investing in precautions and have exposed some of the reasons for the inefficiencies in these investments. See Robert Barr \& Ken Pease, Crime Placement, Displacement, and Deflection, in 12 CRIME AND JUSTICE 277, 289-91 (Michael Tonry \& Norval Morris eds., 1990) (discussing the concept of "malign displacement," which describes situations where the prevention of certain crimes results in the commission of crimes that are more 
spective, this Article aims to facilitate a systematic study of victims' incentives to engage in precautions against crime and of the way criminal law norms shape these incentives. ${ }^{3}$

The normative premise this Article embraces is that of efficiency. It views crime as a social cost that consists of the cost of harm to victims, the cost of precautions against harm taken by victims, and

serious); Ronald V. Glarke, Introduction to Situational Crime PRevention 3, 22-27 (Ronald V. Clarke ed., 1992) [hereinafter Clarke, Introduction] (contrasting the dispositional approach to that of the rational-choice approach in analyzing criminal displacement theory); Ronald V. Clarke, Situational Crime Prevention: Its Theoretical Basis and Practical Scope, in 4 CRIME AND JUSTICE 225, 245-47 (Michael Tonry \& Norval Morris eds., 1983) [hereinafter Clarke, Situational Crime Prevention] (discussing the threat that displacement poses to situational crime prevention measures); Charles $T$. Clotfelter, Private Security and the Public Safety, 5 J. URB. ECON. 388, 398 (1978) (stating that protective measures "may result in an inefficient allocation of resources"); Philip J. Cook, The Demand and Supply of Criminal Opportunities, in 7 CRIME AND JUSTICE 1, 2224 (Michael Tonry \& Norval Morris eds., 1986) (noting that "[s]ome types of selfprotection may pose a hazard to the community"); Derek B. Cornish \& Ronald V. Clarke, Understanding Crime Displacement: An Application of Rational Choice Theory, 25 CRIMINOLOGY 933 (1987) (invoking a framework of criminals' rational decisionmaking to study the theory of crime displacement); David deMeza \& J.R. Gould, The Social Efficiency of Private Decisions to Enforce Property Rights, 100 J. POL. ECON. 561, 579 (1992) (analyzing the effects of externalities arising from private enforcement of property rights); David Friedman, Efficient Institutions for the Private Enforcement of Law, $13 \mathrm{~J}$. LEGAL STUD. 379, 395-96 (1984) (proposing methods to promote a socially efficient system of private law enforcement); Koo Hui-Wen \& I.P.L. Png, Private Security: Deterrent or Diversion?, 14 INT'L REV. L. \& ECON. 87 (1994) (discussing whether private security expenditures deter crime or merely divert it); Thomas A. Reppetto, Crime Prevention and the Displacement Phenomenon, 22 CRIME \& DELINQ. 166 (1976) (examining the argument that crime prevention programs stressing "opportunity reduction" merely displace crime); Steven Shavell, Individual Precautions to Prevent Theft: Private Versus Socially Optimal Behavior, 11 INT'L REV. L. \& ECON. 123, 126 (1991) (stating that individuals' chosen levels of precaution are not necessarily socially optimal levels of precaution). This literature, however, does not offer a victim-centered perspective of criminal law since it does not address the effects of criminal law norms on victims' investments in precautions.

${ }^{3}$ The victim-centered perspective of criminal law restores a symmetry between criminal law and other fields of law. Contract law issues directives to victims of breached contracts as well as to those who have committed such breaches. See infra note 102 and accompanying text. Tort law scrutinizes the behavior of alleged victims of tort as well as that of alleged tortfeasors in order to determine liability. See infra text accompanying note 103 . It has long been understood that different models, studying various areas of law, share a common approach: they focus equally on the behavior of the "passive parties" as on the behavior of the "active parties." See Robert C. Cooter, Unity in Tort, Contract and Property: The Model of Precaution, 73 CAL. L. REV. 1, 44 (1985) (concluding that throughout various areas of law efficiency requires a consideration of the behaviors of both the injurer and the injured). Criminal law has not been commonly understood to fit this unified view. In this sense, the victimcentered perspective that this Article advances unifies our understanding of criminal law with that of other areas of common law. 
the government's enforcement cost. ${ }^{4}$ Inasmuch as criminal law norms are aimed at reducing these costs, studying victims' incentives to take precautions becomes analytically important and economically worthwhile. ${ }^{5}$ This normative premise, however, can be dropped without undermining our main positive claim, namely that crime victims' investments in precautions are affected by criminal law. Thus, if society cares about victims' precautions for reasons other than efficiency, it can use criminal law to influence victims' behavior in a manner deemed desirable.

The victim-centered perspective not only enriches the abstract understanding of criminal law, but also provides an explanation for various existing criminal law doctrines. Doctrines that are ordinarily understood as aimed at influencing perpetrators of crime can now be explained by additional rationales stemming from the incentive effects on potential victims. This Article will demonstrate the usefulness of the victim-centered perspective by applying it to one of the most intractable doctrines in criminal law-the treatment of criminal attempt.

The main insight that runs through the victim-centered perspective is the following: Criminal law norms can induce victims to take efficient levels of precaution by graduating the sanctions imposed upon criminals in accordance with the behavior of their victims. In particular, if a victim takes the efficient level of precaution, her offender will be penalized by a "high" sanction. If a victim takes an inefficient level of precaution, her offender will be penalized by a "low" sanction. The different sanctions will lead to different deterrence: rationally calculating criminals will have an added incentive to target victims who have taken inefficient levels of precaution. Consequently, victims will have an incentive to take the efficient level of precaution.

${ }^{4}$ See, e.g., Gary S. Becker, Crime and Punishment: An Economic Approach, 76 J. PoL. ECON. 169, 170-85 (1968) (discussing the economic costs of crime and the optimal amount of enforcement).

${ }^{5}$ A recent study estimates private expenditures against crime in the United States at about $\$ 300$ billion annually. See Tomas J. Philipson \& Richard A. Posner, The Economic Epidemiology of Crime, 39 J.L. \& ECON. 405, 407 \& n.6 (1996) (applying insights from epidemiology to understand criminal activity and the effects of victims' precautions). Another study finds that in the United States potential victims spent more than $\$ 160$ billion in 1985 alone to physically protect their property. See David N. Laband \& John P. Sophocleus, An Estimate of Resource Expenditures on Transfer Activity in the United States, 107 Q.J. ECON. 959, 962-64 (1992) (estimating, among other things, the social cost of crime prevention). 
Our previous work has already pointed out some of the ways in which criminal law influences victims' behavior. ${ }^{6}$ This Article adds to the study of victims' incentives in two primary aspects. First, it draws a distinction between local and global incentive schemes. Previous work has focused exclusively on local incentives, that is, incentives that encourage or discourage the use of certain specific precautions. ${ }^{7}$ In contrast, this Article points out the importance of using global incentives-incentives that influence the aggregate investment by victims in precautions, regardless of the crime against which they protect themselves or the measures they use. Most importantly, this Article will illustrate that entrenched doctrines of criminal law, in particular the treatment of criminal attempt, provide global incentives for potential victims to change their investment in precautions.

Another way in which this Article extends previous work is its emphasis on the direction of the distortion in victims' behavior. In some previous work, it was assumed that the law needs to induce victims to increase their investment in precautions, which would otherwise be too small. ${ }^{8}$ This Article takes a more comprehensive look at victims' investment in precautions. It exposes several factors that distort the incentives and suggests that the main concern should be victims' overinvestment in precautions. Thus, it argues that criminal law needs to induce victims to reduce their investment in precautions. The doctrine of attempts, it shows, is an incentive mechanism that leads victims to reduce their investment in precautions.

Part I examines the pervasiveness of the perpetrator-centered perspective in the existing law and economics scholarship. It argues that the exclusive focus on the incentives for criminals is incompatible with the welfare-enhancing goals of criminal law. Designing

${ }^{6}$ See Omri Ben-Shahar \& Alon Harel, Blaming the Victim: Optimal Incentives for Private Precautions Against Crime, 11 J.L. ECON. \& ORG. 434, 434-37 (1995) (arguing that "contibutory fault" is used within the criminal law to provide incentives for victims to act in more socially desirable ways); Alon Harel, Efficiency and Faimess in Criminal Law: The Case for a Criminal Law Principle of Comparative Fault, 82 CAL. L. REV. 1181, 1182 (1994) (noting that several criminal law doctrines are "aimed at influencing the behavior of potential victims of crime").

7 See infra text accompanying notes 38-40.

${ }^{8}$ See Harel, supra note 6 , at 1183 (arguing that a criminal law principle of comparative fault would provide victims with incentives to take precautions against criminal acts). But see Ben-Shahar \& Harel, supra note 6, at 434-37 (dropping the assumption of victims' underinvestment in precautions, and focusing the analysis on one factor that may lead to an overinvestment in precautions). 
deterrent measures aimed at criminals is one, but not the only manner in which costs of crime can be curbed. Since victims' investment in precautions is a significant component of the social cost of crime, it is also important to understand what shapes victims' incentives to invest. Part II then analyzes the incentives influencing potential victims. It concludes that there are conflicting forces, and that such conflict may sometimes lead to overinvestment in precautions, and at other times, to underinvestment.

Part III articulates the fundamental proposition of the analysis. It demonstrates how criminal law norms provide incentives for potential victims to engage in precautions. By understanding how these incentives are affected, Part III develops a mechanism that provides optimal incentives.

Part IV explores how traditional doctrines in criminal law, in particular the law of attempts, can be reinterpreted as mechanisms that provide potential victims with incentives to take optimal precautions against crime. It surveys the main, current debates regarding the doctrine of attempts within traditional scholarship and within law and economics. Part IV then addresses one of the most difficult questions that arises in these debates-why do many legal systems treat attempts more leniently than completed crimes? Specifically, why does this leniency exist in situations in which the attempt failed to become a completed crime due to factors beyond the perpetrator's control? In addition, this Part addresses the problem of why a person who engages in mere preparation of a crime is exempted from criminal liability. What are the factors that determine the boundaries between nonpunishable preparation and punishable attempt? In applying the victim-centered perspective to the analysis of criminal attempts, a new justification is developed for the pervasive practice that treats pre-crime activity, such as preparation and attempt, more leniently than completed crimes.

\section{The Dominance of the Perpetrator-Centered Perspective}

Traditional theories of punishment view criminal sanctions exclusively from a perpetrator-centered perspective. A brief sketch of the traditional justifications for criminal sanctions can support this observation. Textbooks of criminal law often state four theories concerning the major functions of punishment: deterrence, retribution, incapacitation and reformation (or rehabilitation).$^{9}$ All

9 See, e.g., Jerome Hall, General Principles of Criminal LAW 297-309 (2d ed. 
of these theories focus exclusively on the actual or potential criminal. Deterrence (either general or specific) is understood as the effort to prevent a potential criminal from committing crimes in the future. ${ }^{10}$ Retributive theories, on the other hand, are interested in inflicting suffering on the actual criminal who, under these theories, deserves to be punished. ${ }^{11}$ Incapacitation focuses on the criminal who cannot be deterred and, hence, should have his libery restricted. Finally, rehabilitation theories study how to reform criminals and return them to society. ${ }^{12}$ Under all of these theories, criminal law focuses on the acts or mental states of criminals (either potential or actual) and regards victims' behaviors or mental states as irrelevant to the concerns of criminal law.

Economic analysis of criminal law joins the general trend of a perpetrator-based perspective. Starting with Gary Becker, ${ }^{13}$ who developed the modern economic model of criminal law, attention has been exclusively devoted to the optimal design of incentives for criminals. In Becker's original analysis, as in many studies that followed, ${ }^{14}$ the focus was on the optimal tradeoff between the

1960) (outlining the general justifications for criminal punishments).

${ }^{10}$ See generally FrankLIN E. ZimRING \& GORDON J. HAWKINS, DETERRENCE: THE LEGAL THREAT IN CRIME CONTROL 70-90 (1973) (detailing the definitions of terms centrally relevant to deterrence theory).

${ }^{11}$ For a good discussion of different theories of retributive justice, see R.A. DUFF, TRIALS AND PUNISHMENTS 187-204 (1986) (describing views that posit retribution as the justification for criminal punishment); C.L. TEN, CRIME, GUILT, AND PUNISHMENT: A PHILOSOPHICAL INTRODUCTION 38-65 (1987) (surveying critically several retributivist theories).

${ }^{12}$ For new attempts to defend rehabilitation theories, see, e.g., DuFF, supra note 11 , at 233-66 (portraying punishment as a means to secure the criminal's repentance for his wrongdoing); Jean Hampton, The Moral Education Theory of Punishment, 13 PHIL. \& PUB. AFF. 208, 221-28 (1984) (arguing for a moral education theory of punishment). Admittedly, there are theories of punishment that cannot be easily categorized under these four headings. Such theories, however, have not been influential in legal circles. The most prominent of these theories is the expressive theory of punishment, which regards punishment as expressing societal condemnation of criminal behavior. See DUFF, supra note 11, at 235-39 (stating that punishment expresses condemnation and disapproval of the criminal act); Joel Feinberg, The Expressive Function of Punishment, in A READER ON PUNISHMENT 71 (R.A. Duff \& David Garland eds., 1994) (depicting punishment as an expression of disapproval and condemnation). The expressive theory, however, is not exempted from the deficiencies of the other theories. For our purposes it is sufficient to note that it focuses solely on the criminal and neglects the role of the victim.

${ }^{13}$ See Becker, supra note 4, at 170-85 (discussing the economic cost of crime and the optimal amount of enforcement).

14 See generally James Andreoni, Reasonable Doubt and the Optimal Magnitude of Fines: Should the Penalty Fit the Crime?, 22 RAND J. OF ECON. 385 (1991) (reexamining models of the enforcement-compliance relationship and concluding that in a judicial system 
magnitude of sanctions and the probability of apprehending the criminal. These analyses concentrated on the most efficient means by which society can deter criminals from committing harmful acts. In this entire branch of literature, victims' roles were limited to the suffering of harm; monitoring victims' behavior was not considered a policy objective. ${ }^{15}$

premised on a "reasonable doubt" standard, increased penalties reduce probabilities of conviction); Lucian A. Bebchuk \& Louis Kaplow, Optimal Sanctions When Individuals Are Imperfectly Informed About the Probability of Apprehension, $21 \mathrm{~J}$. LEGAL STUD. 365 (1992) (reconsidering levels of optimal sanctions in cases involving perpetrators' uncertainty of the probability of capture); Louis Kaplow, Optimal Deterrence, Uninformed Individuals, and Acquiring Information About Whether Acts Are Subject to Sanctions, 6 J.L. ECON. \& ORG. 93 (1990) (examining levels of optimal enforcement in cases involving legal uncertainties in the acts committed); Louis Kaplow, The Optimal Probability and Magnitude of Fines for Acts that Definitely Are Undesirable, 12 INT'L REV. L. \& ECON. 3 (1992) (examining the optimal measures of enforcement when the optimal level of crime is known to be zero); Arun S. Malik, Avoidance, Screening and Optimum Enforcement, 21 RAND J. OF ECON. 341 (1990) (suggesting that high sanctions may lead to excessive efforts toward detection avoidance); Dilip Mookherjee \& I.P.L. Png, Monitoring vis-à-vis Investigation in Enforcement of Law, 82 AM. ECON. REV. 556 (1992) (suggesting a varied investigation rate and maximal fines to optimally deter larger offenses); A. Mitchell Polinsky \& Steven Shavell, Enforcement Costs and the Optimal Magnitude and Probability of Fines, 35 J.L. \& ECON. 133 (1992) (examining how enforcement costs affect optimal degrees of enforcement effort and optimal magnitude of sanctions, and concluding that certain enforcement costs, including costs of investigation and prosecution, should be included in imposing fines); A. Mitchell Polinsky \& Steven Shavell, A Note on Optimal Fines When Wealth Varies Among Individuals, 81 AM. ECON. REV. 618 (1991) (concluding that optimal deterrence is achieved when fines are less than the entire wealth of most individuals); A. Mitchell Polinsky \& Steven Shavell, The Optimal Tradeoff Between the Probability and Magnitude of Fines, 69 AM. ECON. REv. 880 (1979) (reexamining Becker's model under the assumption of risk-aversion); A. Mitchell Polinsky \& Steven Shavell, The Optimal Use of Fines and Imprisonment, 24 J. PUB. ECON. 89 (1984) (concluding that maximal fines should be imposed before a sanction is supplemented with imprisonment); Steven Shavell, Specific Versus General Enforcement of Law, 99 J. POL. ECON. 1088 (1991) [hereinafter Shavell, Specific Versus General] (suggesting that where enforcement efforts are general, optimal sanctions rise in proportion to the harmfulness of acts); George J. Stigler, The Optimum Enforcement of Laws, $78 \mathrm{~J}$. POL. ECON. 526 (1970) (suggesting that imposing maximal sanctions for all crimes undermines "marginal deterrence," i.e., eliminating the incentive of an individual who commits one crime to refrain from committing another, more serious crime). For a recent survey of the economic literature on criminal law enforcement, see Nuno Garoupa, The Theory of Optimal Law Enforcement, $10 \mathrm{~J}$. ECON. SURV. (forthcoming 1997).

${ }^{15}$ A typical model belonging to this literature would have a "population" of potential criminals who are rational calculators, and who stand to gain a benefit ("b") if they commit the harmful act. Their act imposes a harm (" $h$ ") on the victim and on society. Society can invest a cost of " $x$ " in detecting criminals, to bring the probability of detection to $p(x)$. If caught, the criminal is punished by a sanction (" $s$ "). Thus, a risk-neutral individual would commit the act if and only if $b>p(x) \times s$. Becker demonstrated that any given enforcement policy can be improved simply by increasing 
Posner and Shavell each have extended the Becker-type analysis to study a broader set of issues relating to criminal enforcement. Posner posited that criminal sanctions should be designed to generate deterrence where tort liability and monetary "fines" are ineffective (due to the actor's solvency problems, or to the inherently low probability of detection). ${ }^{16}$ Shavell studied the optimal use of nonmonetary sanctions-ones that are costly for society to administer. ${ }^{17}$ Both Posner and Shavell used their theories to rationalize various criminal doctrines, including intent, attempt, causation, conspiracy and defenses. In doing so, they have continued the trend of focusing exclusively on criminals as the only parties whose behavior should be monitored.

Lately, economists have devoted increasing attention to the incentives operating upon potential victims. ${ }^{18}$ Recognizing that victims' investments in precautions are a significant economic activity, estimated by some to cost hundreds of billions of dollars each year, ${ }^{19}$ economists examine whether this investment is excessive. These studies advance the understanding of victims' incentives and highlight the divergence between the good of individual victims

the sanctions and reducing the probability of detection by the same proportion. See Becker, supra note 4, at 170-85. Deterrence would remain unchanged, while some costs of detection would be saved. If Becker's logic is followed to an extreme, it would prescribe the administration of maximal sanctions, coupled with very low probabilities of detection. The literature that followed Becker, some of which is referred to in note 14, supra, tried to reexamine Becker's model under more complex assumptions, and to determine when low sanctions would be desirable. See, e.g., Stigler, supra note 14, at 527 .

${ }^{16}$ See Richard A. Posner, An Economic Theory of the Criminal Law, 85 COLUM. L. REV. 1193, 1195 (1985) (noting that not all "market bypassing [can] be deterred by tort law").

${ }^{17}$ See Steven Shavell, Criminal Law and the Optimal Use of Nonmonetary Sanctions as a Deterrent, 85 CoLUM. L. REV. 1232, 1241-42, 1246 (1985) (recognizing how the nature of the court's information can explain the optimal levels of sanctions).

${ }^{18}$ See Ian Ayres \& Steven D. Levitt, Measuring Positive Externalities from Unobservable Victim Precaution: An Empirical Analysis of Lojack 5-10 (Aug. 1996) (unpublished manuscript, on file with the Yale Law School) (examining the distorted incentives to install the Lojack car antitheft device); Hui-Wen \& Png, supra note 2, at 95-97 (examining whether victims' precautions deter or merely divert crime); Keith N. Hylton, Optimal Law Enforcement and Victim Precaution, 27 RAND J. ECON. 197 (1996) (showing how optimal enforcement changes when victim precautions are taken into account); Shavell, supra note 2, at 123 (examining the individual or collective motives of private individuals to protect their property from theft).

${ }_{19}$ See Laband \& Sophocleus, supra note 5, at 962-63; Philipson \& Posner, supra note 5, at $407 \&$ n.6. The former estimates that victims spend more than $\$ 160$ billion annually on merely protecting the physical access to their property, and the latter estimates that up to $\$ 300$ billion are spent annually on crime-reducing activities. 
and the good of society. What these studies do not do, however, is point out the connection between the criminal law and victims' investments in precautions against crime. ${ }^{20}$

In sum, economists have addressed both criminal law and victims' investment in precautions, but they have failed to explore the relationship between the two. Economists who devoted their attention to criminal law ignored its effects on victims. ${ }^{21}$ Economists who devoted their attention to victims' behavior-in particular, to their investment in precautions-failed to explore how criminal law influences that behavior. ${ }^{22}$ Thus, despite economists' explicit urgings to reconsider and challenge traditional justifications for criminal law norms, economists have widely endorsed a perpetratorcentered perspective-the very same perspective that characterizes the more traditional scholarship of criminal law.

This conclusion is surprising for two reasons. First, there is an important sense in which the perpetrator-centered perspective endorsed by Becker, Posner, Shavell and others is incompatible with the fundamental presuppositions of their own theories. Efficiency considerations dictate that criminal law should minimize the total costs of crime to society, defined as the sum of the expected costs of crime and the costs of precautionary measures against crime. ${ }^{23}$ If the fundamental objective of criminal law is to minimize the costs of crime as defined above, criminal law norms should be evaluated with respect to their effect on the incentives operating upon potential victims to take efficient precautions.

Second, the emergence of economic analysis as an independent school of thought is often attributed to Ronald Coase, through his article The Problem of Social Cost. ${ }^{24}$ One of the most influential insights of Coase's article is the attention it draws to the incentives operating upon potential victims of torts to invest in precautionary measures and the manner in which these incentives can be manipu-

${ }^{20}$ One area of victim activity that has produced many studies is carrying concealed handguns. Estimates of the frequency of defensive use of guns range from 80,000 to 2.5 million occurrences each year. See, e.g., Gary Kleck \& Marc Gertz, Armed Resistance to Crime: The Prevalence and Nature of Self-Defense with a Gun, $86 \mathrm{~J}$. CRIM. L. \& CRIMINOLOGY 150,153, 180-82 (1995) (surveying the prevalence of defensive uses of guns each year).

${ }^{21}$ See supra notes 13-16 and accompanying text.

22 See supra notes 16-18 and accompanying text.

${ }^{23}$ See Becker, supra note 4, at 200, 207; COOTER \& ULEN, supra note 1, at 536-39.

${ }^{24} 3$ J.L. \& ECON. 1 (1960) (illustrating the law's irrelevance to the attainment of efficiency, and suggesting that fundamental legal distinctions are economically insignificant). 
lated through tortfeasors' liability. ${ }^{25}$ Why has this insight not been imported from the economic analysis of tort law into the economic analysis of criminal law?

Three arguments can perhaps justify this failure on the part of economists to explore the manner in which criminal law influences victims' behavior. The first is a division of labor argument. Under this argument, criminal law is a means of providing incentives for criminals. Arguably, other mechanisms are better suited to provide incentives for potential victims to take efficient precautions against crime. Unfortunately, few attempts have been made to explore systematically alternative mechanisms by which potential victims can be induced to invest efficiently in precautions. ${ }^{26}$

The second argument questions whether criminal law can significantly influence the incentives of potential victims to take precautions against crime. Criminal law imposes sanctions on criminals and hence primarily influences the incentives operating upon criminals. Part III will contest this argument and demonstrate that criminal law inevitably provides some incentives for potential victims to invest in precautions and that it is therefore important to adopt rules that provide victims with incentives to invest efficiently in precautions.

The third argument endorses the view that victims' incentives to take precautions against crime are optimal under the current system and, therefore, that there is no need to tinker with these incentives. Arguably, victims of crime bear the full expected costs of the crime directed against them. Consequently, they have adequate incentives to take optimal precautions. If these incentives are optimal, any attempt to influence potential victims will distort the efficient incentives that already operate under the current system. The following Part will explore the incentives operating on potential victims and expose the distortions in these incentives. It will conclude that, given these distortions, and absent a corrective mechanism, victims' investments in precautions are likely to be inefficient.

${ }^{25}$ See also John Prather Brown, Toward an Economic Theory of Liability, 2 J. LEGAL STUD. 323, 348-49 (1973) (using economic analysis to compare the social efficiencies of different tort liability rules).

${ }^{26}$ This neglect is evident in light of the extensive literature on victims' incentives in other areas of law. See, e.g., Cooter, supra note 3, at 3 (positing a model of precaution that highlights the fundamental role of victims in reducing the costs of interfering activities). 


\section{The Distorted Incentives of Potential CRIME Victims}

Potential victims take precautions to reduce the costs of crime they bear. In situations in which potential victims bear the full expected costs of crimes directed against them and the full cost of their own precautions, we can expect their investment in precautions to be optimal. In such situations, any attempt to induce potential victims to change their investment in precautions will lead to inefficiencies. If, however, victims' precautions generate external effects such that the well-being of other individuals is affected, then we can predict that victims' investment in precautions will not be optimal. The discussion below examines several external effects that victims' precautions may have. First, we look at factors that may lead to overinvestment in precautions, and then, we consider factors that may lead to underinvestment in precautions.

\section{A. Overinvestment in Precautions}

Victims may overinvest in precautions when those precautions generate negative externalities, i.e., if there are costs that they do not bear that arise from their precautions. The following are examples of when precautions might impose external costs.

\section{Crime Diversion}

One factor that may lead to excessive investment in precautions, and which has gained much attention in the literature, is the diversion or displacement of crime. ${ }^{27}$ Often, precautions are

${ }^{27}$ See, e.g., Barr \& Pease, supra note 2, at 283-93 (examining "how displacement or deflection of crime can be used to achieve [an equitable] spread of crime"); Clarke, Introduction, supra note 2, at 22-25 (noting that "displacement is always a danger, but is rarely if ever complete"); Clarke, Situational Crime Prevention, supra note 2, at 227, 245-47 (describing "the range of displacement effects that have been observed and hypothesized" and reviewing "selected research findings on whether, when and to what extent displacement occurs"); Clotfelter, supra note 2, at 398 (arguing that "protective measures which have the effect of diverting crime from one household to others constitute a class of externalities which may result in an inefficient allocation of resources"); Cook, supra note 2, at 1, 14-19 (discussing the relationship between opportunities for crime and the aggregate amount of crime); Cornish \& Clarke, supra note 2 (invoking a framework of criminals' rational decisionmaking to study the theory of crime displacement); Hui-Wen \& Png, supra note 2, at 94 ("[A]dditional security expenditures by one victim surely will divert criminals to the other."); Reppetto, supra note 2, at 166 (arguing that "there are definite limits to various displacement possibilities" and that "the displacement potential of an anticrime strategy can be gauged in advance and, in certain instances, be minimized"); Shavell, supra note 2 (considering the theft reduction effect plus the diversion effect if 
successful in preventing harm to the victim that installed them, yet at the same time divert the criminal toward acting against other, less protected, victims. If, for example, a potential victim builds an impenetrable fence around his house, a theft that would otherwise have occurred at his house may now occur at a neighboring estate. Similarly, if a car owner installs a sophisticated antitheft device, the car thief may find his victim farther down the street. Whenever precautions lead merely to crime diversion, they have no social value since they do not reduce the social cost of crime. Thus, society would prefer that these precautions were not used. But since these diverting precautions have a private value to their users, they will in fact be utilized. Hence, the actual private use of these precautions exceeds the socially optimal level: crime diversion leads to excessive precautions.

\section{Criminals' Benefit}

There is an ongoing debate as to whether criminals' benefit from crime ought to be included in the social welfare calculus at all, namely, whether society is considered better off if, other things being equal, its criminals are wealthier. ${ }^{28}$ Put differently, if one considers theft to be a mere transfer of wealth, from the victim to the criminal, one is implicitly including the criminals' benefit as an element of social welfare. Hence, if we put some positive value on criminals' benefit, even if this value is discounted significantly, we are faced with the concern that criminals' benefits will be deprived by victims' overinvestment in precautions. If criminals' benefit from crime is

precautions are observable or unobservable). For a discussion of this phenomenon in the context of the right to carry handguns, see Daniel D. Polsby, Firearms Costs, Firearms Benefits and the Limits of Knowledge, 86 J. CRIM. L. \& CRIMINOLOGY 207, 207-220 (1995) (questioning whether carrying firearms reduces the threat of homicide or merely diverts it).

${ }^{28}$ Becker suggested originally that criminals' benefit should be counted as part of social welfare. See Becker, supra note 4, at 173 (including the gain to offenders when calculating the total harm to society from crime). In a famous response, George Stigler argued the contrary. See Stigler, supra note 14, at 527-28 (asking "what evidence is there that society sets a positive value upon the utility derived from murder, rape, or arson"). For a survey of law and economics writers' positions in this debate, as well as for arguments why criminals' benefits should not count, see Jeff $L$. Lewin \& William N. Trumbull, The Social Value of Crime?, 10 INT'L REV. L. \& ECON. 271,278 (1990) ("Treating criminal gains as a contribution to social welfare ignores the reality that certain acts . . . are expressly prohibited by criminal legislation."), and the response by Fred S. McChesney, Boxed In: Economists and Benefits from Crime, 13 INT'L REV. OF L. \& ECON. 225, 228-29 (1993) (criticizing Lewin and Trumbull's arguments as economically unconvincing). 
part of social welfare, then victims' precautions that reduce criminals' benefits reduce social welfare. With greater precautions, a successful crime becomes harder to accomplish, and the benefit that criminals gain from it is less often realized.

\section{Harm from Precautions}

Often, victims' precautions involve hazardous activities that, aside from preventing the completion of the crime, may also harm either other potential victims or the criminals themselves. For example, potential victims who carry defensive weapons occasionally use them inaccurately, harming other victims or the criminals unnecessarily. ${ }^{29}$ Alternatively, home and car alarms that are set off inadvertently may cause noise nuisances that harm neighbors. As these costs are not borne entirely by the victims who employ the precautions, victims have the tendency to utilize them excessively.

\section{B. Underinvestment in Precautions}

If the precautions generate positive externalities, i.e., if there are certain benefits that would arise from using precautions which victims do not appropriate, then victims will tend to underinvest in those precautions. Two such external benefits are deterrence as a public good and prevention of future harms.

\section{Deterrence as a Public Good}

Some precautions have a "public good" aspect: once installed, they benefit other victims as well. ${ }^{30}$ Take, for example, a streetlight that a homeowner installs in front of her house to deter burglars. Other homeowners whose gates are illuminated by the light benefit from it without bearing its cost. Similarly, the precautionary

${ }^{29}$ See Philip J. Cook, The Role of Firearms in Violent Crime: An Interpretive Review of the Literature, in CRIMINAL VIOLENCE 236 (Marvin E. Wolfgang \& Neil Alan Weiner eds., 1982) (suggesting that many deaths can be eliminated by keeping guns out of the possession of potential victims).

${ }^{30}$ Public goods are characterized by two features: 1) jointness of supply and 2) the impossibility or inefficiency of exclusion. Jointness connotes that the consumption of the public good by one person does not detract from the benefits enjoyed by others. The impossibility or inefficiency of exclusion means that consumers cannot easily be excluded from enjoying or benefitting from the public good. For a more detailed definition of public goods, see JOSEPH STIGLITZ, ECONOMICS OF THE PUBLIC SECTOR 119-23 (2d ed. 1988) (claiming the two features of public goods to be the nondesirability of rationing and the nonfeasibility of rationing). 
measures that stockholders in a corporation take to prevent embezzlement by corporate officials benefit all other stockholders. The social gain from these types of precautions exceeds the private gain to the victims who implement them, implying that some socially valuable measures will not be applied. ${ }^{31}$

\section{Prevention of Future Harms}

Victims' precautions may yield benefits distinct from the immediate benefit for which they were intended. If detection measures (e.g., closed-circuit cameras) lead to the apprehension and incapacitation of criminals, future potential victims of these apprehended criminals benefit. Likewise, if the failure to succeed in crime leads some criminals to turn to legal activities, the precautions that led to this failure benefit future potential victims. But since the victims that choose these precautions do not appropriate their entire future benefit, underinvestment in precautions occurs.

Hence, there are various factors that may distort victims' incentives to take precautionary actions. Some precautions may be used excessively, while others may be used suboptimally. Empirical examination may determine which activity is subject to which type of distortion. For the purpose of this discussion, it suffices to conclude that, in general, we cannot expect victims to engage in optimal precautions. Later in the analysis, we will offer some conjectures regarding the actual direction of the distortion, whether it is towards over- or underinvestment. ${ }^{32}$ But first let us begin by proposing a general analytical solution to the inefficiency-a solution that applies independently of the direction of the distortion.

${ }^{31}$ This phenomenon has been noted by criminologists as well as by economists. See Ayres \& Levitt, supra note 18, at 30-31 (demonstrating that the Lojack car antitheft device is currently underutilized, in part due to the fact that consumers using the device obtain less than $10 \%$ of the total social benefit produced by it); Clarke, Introduction, supra note 2, at 25-26 (describing the "diffusion of benefits" that occurs when anticrime measures in one arena provide benefits in others); Terance $D$. Miethe, Citizen-Based Crime Control Activity and Victimization Risks: An Examination of Displacement and Free-Rider Effects, 29 CRIMINOLOGY 419, 422 (1991) (discussing the "free-rider" effect for residents who do not take significant precautions against crime); Shavell, supra note 2, at 124-26 (comparing the "potential victims' collectively optimal level of precaution" to the level of precaution taken by just one individual).

32 See infra Part IV.D.1. 


\section{How Gan Victims' InCENTIVEs Be Changed Through CRIMINAL LAW?}

\section{A. Providing Victims' Incentives Through Criminal Law}

As explained above, potential victims may sometimes take excessive precautions, and other times engage in too few precautions. This Part will explore the means by which criminal law can simultaneously provide incentives for those victims who invest too much in precautions to reduce their investment and for those who invest too little to increase their investment.

Demonstrating how criminal law provides incentives for victims requires a two-stage analysis. At the first stage, we will show that criminal law can influence the manner in which perpetrators of crime choose their victims. At the second stage, we will show that the shift in the way in which perpetrators select their victims-a shift which can be induced by criminal law norms-in turn influences the investment of potential victims of crime in precautionary measures.

Criminal law can influence the manner in which criminals select their victims by graduating the sanctions imposed upon criminals in accordance with their victims' behavior. Harsher sanctions would be imposed on criminals who target victims who had taken optimal precautions. This system would deter criminals from targeting such victims and, consequently, would lead victims to take optimal precautions. To illustrate how this mechanism would work, consider the following example. Assume a society consisting of two types of potential victims, type $A$ and type $B$. Type $A$ victims engage in optimal precautions, while type B victims take an inefficient amount of precautions. Criminal law norms can impose harsher sanctions on criminals who target type A victims than on criminals who target type $B$ victims. Such a rule encourages rationally calculating criminals to shift from type A victims to type B victims and consequently imposes larger expected costs on type B victims. ${ }^{33}$ The increased risks borne by type $B$ victims will, in turn, induce potential victims to behave in the desired manner and thus enjoy the increased protection enjoyed

33 This result could also be achieved if, instead of raising the sanctions imposed upon criminals who select type A victims, society were to increase its enforcement efforts in a way that raises the probability that criminals who direct their crime against type $A$ victims will be caught and punished. In order to manipulate the manner by which criminals select their victims, one needs to differentiate the expected punishment across victims, i.e., the magnitude of the sanction multiplied by the probability of being apprehended and convicted. 
by type A victims. Criminal law can thus induce potential victims to engage in an efficient amount of precautions by manipulating criminals' punishment.

Provided certain premises are satisfied, this result applies to a broader set of victims' behaviors, some even outside the context of precautionary activity. Theoretically, criminal law can provide incentives to potential victims to respect their neighbors, contribute to charitable organizations, or pay their taxes, simply by imposing harsher sanctions on criminals who target victims who conform with these norms. The broad spectrum of desirable behaviors which, theoretically, can be reinforced through this mechanism raises difficult moral questions regarding the proper role of criminal law in regulating society. ${ }^{34}$ This Part will focus exclusively on one type of behavior that the law wishes to encourage, namely efficient investment in precautions against crime.

The diverse and conflicting incentives operating on potential victims lead some to invest too much in precautions and others to invest too little. The legal system should provide potential victims with incentives in order to effectuate a larger investment in precautions on the part of those who invest too little, as well as a smaller investment in precautions on the part of those who invest too much. It is our goal to show that proper incentives can be provided to potential victims, which will promote desirable behavior even when the directions of the distortions vary-that is, when victims tend to engage in both too low or too high a level of precaution.

Let us change our example and assume that there are now three classes of victims: type A victims who still invest optimally in precautions, type $B$ victims who invest more than efficiency requires and type $G$ victims who invest less than efficiency requires. Criminal law can simultaneously induce type $B$ victims and type $C$ victims to invest optimally as well as preserve the incentives operating on type A victims to invest optimally. Lower penalties meted out to criminals who direct their activity against types $B$ and $C$ victims will induce criminals to target victims of types $B$ and $C$. This will induce type $B$ and type $\mathrm{C}$ victims to modify their investment in precautions in accordance with efficiency. At the same time, the higher penalties that protect type A victims reinforce their choice of optimal behavior.

${ }^{34}$ We are grateful to Scott Altman for first raising this objection. For a detailed discussion, see infra Part IV.D.4.c. 
This reasoning is premised on two implicit assumptions that need to be established. First, precautions can influence the victimselection by criminals only when victims' precautions can be observed by criminals in advance. Nonobservable precautions cannot affect criminals' behavior and consequently cannot influence victims' investments in precautions. ${ }^{35}$ Second, it may seem that criminals' behavior can influence victims' investments in precautions only if potential victims understand and anticipate the patterns of criminals' decisionmaking and, in particular, the considerations influencing criminals' decisions to target one victim rather than another. Let us examine these premises and the degree to which they can be satisfied.

Most precautions taken by victims are visible and can be detected by criminals. The use of locks, bars, steel doors and many other conventional precautions are visible and thus can influence the way in which criminals select their victims. Even when precautions are not visible, victims often notify potential criminals of the existence of the precautions. ${ }^{36}$ A successful crime requires a thorough investigation of the precautions potential victims take. It is reasonable, therefore, to presume that criminals invest resources in identifying victims' precautions prior to the crime. ${ }^{37}$

It is more difficult to establish the second presupposition, namely that potential victims anticipate the considerations influencing criminals' selections of victims. Fortunately, such a presupposition is not required for the purposes of this Article. One need not assume that potential victims know how criminals select their victims in order to establish the claim that potential victims behave as if they had such knowledge. We believe that this latter proposition can be established.

Potential victims are likely to know the efficacy of precautions against crime. In particular, they will inquire as to how often

35 See Ben-Shahar \& Harel, supra note 6, at 451-53 ("If criminals cannot observe the victim's conduct, they cannot distinguish between [a victim who takes precautions and one who does not] .... In this case, the victim may not be led to comply since compliance does not affect the incentives of criminals.").

${ }_{36}$ This practice raises interesting issues regarding the credibility of such notices. See id. at 451-52 ("The victim . . . [may] simulate protection measures without actually applying them.").

${ }_{37}$ There is some evidence, for example, that burglars expend effort "casing" a house to evaluate its protection and ensure that no one is home. SeeJAMES D. WRIGHT \& PETER H. ROSSI, ARMED AND CONSIDERED DANGEROUS: A SURVEY OF FELONS AND THEIR FIREARMS 140 (1986) (noting that "most burglaries occur when the homes in question are unoccupied"). 
potential victims who use a particular precaution are victimized. If criminals are less likely to target potential victims who invest efficiently in precautions, those victims will be less prone to victimization and, consequently, other potential victims will be induced to invest efficiently. Potential victims need not understand the precise mechanisms that operate here; in particular, they need not understand that a low rate of victimization should be attributed to the incentives provided by criminal law. All that is assumed is that victims do not make systematic errors in understanding and learning from the experience of others. ${ }^{38}$ Hence, a system that differentiates criminals' punishments according to their victims' precautions can induce optimal precautions even if victims do not fully comprehend the manner in which the system operates.

If the two presuppositions underlying this argument are sound, victims' investments in precautions can be manipulated by providing incentives to criminals to shift from victims who invest efficiently in precautions to victims who invest too much or too little in precautions. Criminals will react to these incentives accordingly and potential victims will adjust their investment in precautions to conform with the dictates of efficiency.

\section{B. Global Versus Local Incentives}

Once the mechanisms for providing incentives to potential victims are clarified, one can classify these incentives into two major types, global and local incentives. Global incentives affect and alter indiscriminately the incentives of potential victims to invest in precautions. Local incentives, on the other hand, are designed to encourage or discourage potential victims from taking specific precautions.

${ }^{38}$ This assumption resembles the assumption of rational expectations in economic models. The concept of rational expectations implies that, in the long term, individuals do not make forecasting errors and do not base their behavior upon consistently misguided beliefs. Their assessment of the information is no worse than the assessment that can be made by the economist who studies the model. Either by learning, evolution, or the inherent laws of statistics, individuals' assessments are assumed to be correct, on average. See Thomas Sargent, Rational Expectations, in 4 THE NEW PALGRAVE: A DICTIONARY OF ECONOMICs 76 (John Eatwell et al. eds., 1987) (describing the "defining property" of a model with rational expectations to be "that the forecasts made by agents within the model are no worse than the forecasts that can be made by the economist who has the model"). Thus, if criminals follow a given pattern of behavior, such as in the choice of victims as suggested above, victims will subsequently behave as if they expect such patterns of choice from criminals, even if these victims do not have the specific knowledge regarding criminals' motivations. 
It is important to specify the circumstances that justify the use of global incentives and those that justify the use of local incentives. The use of global incentives does not require any judgment concerning the efficiency of any specific precaution. It requires a judgment concerning the overall patterns of behavior of potential victims, in particular, whether potential victims as a whole over- or underinvest in precautions. If one knows that most potential victims will overinvest, one can provide global incentives to decrease investment in the precautions and remedy this inefficiency. Alternatively, if one knows that most potential victims will underinvest, one can design global incentives aimed at increasing the overall investment in precautions. Local incentives, in contrast, can be utilized precisely under the opposite circumstances. In order to use local incentives, one need not make judgments as to whether most victims are likely to overinvest or underinvest in certain precautions. Instead, one needs to judge the desirability of a certain precaution, and whether its use should be reinforced or discouraged.

Problems of inefficient investment can be addressed by criminal law norms that have either global or local applicability. A norm that provides global incentives will be appropriate whenever there is a phenomenon of global inefficient investment, while norms that provide local incentives will be desirable whenever victims invest suboptimally in a particular precaution. The remaining task is to supply this general approach with concrete substance and to demonstrate how it applies in practice, i.e., to describe criminal law doctrines that serve to manipulate victims' investments in precautions.

There are many examples of criminal law's use of local incentives in controlling the victims' behavior. Mitigating the punishment for offenders who commit homicide as a result of provoked, uncontrollable passion provides incentives to potential victims to abstain from provocative behavior. ${ }^{39}$ Criminal law increases the risks imposed upon provokers and thus increases the costs of provocation. Similarly, the "no retreat rule," under which a person is permitted to use deadly force to combat an attack directed against her even if she could have avoided using the deadly force by retreating, is a means

${ }^{39}$ See Harel, supra note 6, at 1211-17 (interpreting the doctrine of provocation as an instance of a comparative fault scheme designed to deter individuals from provoking others). 
to increase the risks imposed upon the victim (who is in this particular case the initial aggressor). ${ }^{40}$

These doctrines, however, cannot remedy the general disposition of potential victims to invest suboptimally in precautions because of the limited scope of their operation. They can merely provide local incentives that induce potential victims to take specific precautions against specific crimes, based upon a judgment that a certain precaution is efficient and, therefore, that its use should be encouraged. None of these doctrines, however, can remedy a more global phenomenon of inefficiency, namely a disposition on the part of victims to over- or underinvest in all types of precautionary measures. The next Part will analyze the law of pre-crime activities and interpret it as providing global incentives to potential crime victims to reduce their investment in precautions. ${ }^{41}$ The global applicability of the law governing pre-crime activities highlights the importance of endorsing a victim-centered perspective in criminal law.

\section{The Treatment of Pre-CrIme Activities:}

A Victim-Centered PerspeCtive

\section{A. Introduction}

The perpetrators of pre-crime activities such as attempt and preparation are treated leniently under traditional criminal law. Attempts are punished less severely than completed crimes and preparation ordinarily is not subject to criminal liability at all.

Most U.S. jurisdictions stipulate that the perpetrator of an attempted crime will be punished less severely than the perpetrator of a completed crime. ${ }^{42}$ The rule is pervasive, despite a wide range of critiques directed against it. ${ }^{43}$ The Model Penal Code's ("MPC")

${ }^{40}$ See id. at 1217-19 (discussing the rationale of the "no retreat rule").

${ }^{41}$ Pre-crime activities include, under our definition, both preparation and attempt.

42 See, e.g., CAL. PENAL CODE $\$ 664$ (West 1988) (establishing sentences for attempts at one-half the length of those for the completed crimes); N.Y. PENAL LAW $\S 110.05$ (McKinney 1987) (classifying, with certain exceptions, attempts as one grade below the completed crime).

${ }^{43}$ Some foes of the practice believe that attempts should not be punished at all. See, e.g., Lawrence Crocker, Justice in Criminal Liability: Decriminalizing Harmless Attempts, 53 OHIO ST. L.J. 1057, 1109 (1992) (arguing that absent the imposition of an immediate objective risk there ought to be no liability for attempts). Most critics believe that the attempt should be punished in the same manner as the completed crime. See, e.g., Lawrence Becker, Criminal Attempt and the Theory of the Law of Crimes, 3 PHIL. \& PUB. AfF. 262 (1974) ("[I]n many cases, successful crimes and (the 
proposal to change the rule and equalize the sanctions imposed for attempted crimes with those imposed for completed crimes has been rejected by most jurisdictions in the United States. ${ }^{44}$

The persistence of the practice despite the wide range of criticism is indicative of deep-seated sentiments-sentiments that were articulated by Adam Smith over 200 years ago:

Our resentment against the person who only attempted to do a mischief, is seldom so strong as to bear us out in inflicting the same punishment upon him, which we should have thought due if he had actually done it. In the one case, the joy of our deliverance alleviates our sense of the atrocity of his conduct; in the other, the grief of our misfortune increases it. ${ }^{45}$

Smith was also quick to identify a conflicting intuition which guided most of the critics of the practice: "His real demerit, however, is undoubtedly the same in both cases, since his intentions were equally

corresponding) attempted crimes should be punished equally."); Sanford Kadish, Supreme Court Review, Foreword: The Criminal Law and the Luck of the Draw, 84 J. CRIM. L. \& CRIMINOLOGY 679, 679 (1994) (arguing that the practice of punishing attempts less severely than completed crimes is "not rationally supportable" by any theory of criminal punishment).

${ }^{44}$ There are, however a few states that have equalized the sanction. See, e.g., ConN. GEN. STAT. ANN. § 53a-51 (West 1958) (providing that an attempt to commit a crime is generally a felony of the same class and degree as a completed crime); DEL. CODE ANN. tit. 11, §531 (1995) (same). It is interesting to compare the situation in the United States with that in other common law jurisdictions. Some commentators have argued that the gap between the sanctions for attempts and completed crimes is gradually eroding in common law countries. See Yoram Shachar, The Fortuitous Gap in Law and Morality, 6 CRIM. JUST. ETHICs 12, 13 (1987) (“[P]unishment for attempt has slowly ... gain[ed] parity with maximum punishment in many of the common law jurisdictions, most notably in England itself and in many of the American states."). Indeed, some foreign jurisdictions changed their law to allow the judge to impose the same sanction for attempts and completed crimes. See, e.g., Griminal Attempts Act, 1981, ch. $47, \S 4$ (Eng.) (equalizing the punishment for attempts and completed crimes); THE PENAL CODE OF THE FEDERAL REPUBLIC OF GERMANY, § 23(2) (Joseph J. Darby trans., 1987) (1975) (stating that "[a]n attempt may be punished less severely than the completed crime," implying that an attempt may also be punished as severely); THE PENAL CODE OF ISRAEL, $\$ 34$ (d) (1977). But even in these cases, there are important exceptions to the rule. See, e.g., Criminal Attempts Act, 1981, ch. 47, \$ 4(5) (Eng.) (maintaining attempt liability structure contained in Sexual Offenses Act of 1956); THE PENAL CODE OF ISRAEL, $\$ \S 27,34$ (c) (1977). It has been noted that even when the legislature imposes similar sanctions for attempts and completed crimes, in practice the punishment for an attempt is less than the punishment for a consummated crime. See GlanVille Williams, TeXtbook ON Criminal LaW 404 (2d ed. 1983) (noting that the attempter usually will be punished less severely than the criminal who completed the crime).

${ }^{45}$ ADAM SMITH, THE THEORY OF MORAL SENTIMENTS 188 (Liberty Classics 1976) (1759). 
criminal; and there is in this respect, therefore, an irregularity in the sentiments of all men, and a consequent relaxation of discipline in the laws of, I believe, all nations." 46

Contemporary scholarly literature has not advanced much beyond the astute observations of Adam Smith. ${ }^{47}$ The basic conflicting intuitions identified by Adam Smith remain intact. On the one hand, a completed crime raises more resentment and outrage than an unsuccessful attempt to commit the very same crime. ${ }^{48}$ On the

${ }^{46} I d$.

${ }^{47}$ See Björn Burkhardt, Is There a Rational Justification for Punishing an Accomplished Crime More Severely Than an Attempted Crime?, 1986 B.Y.U. L. REv. 553, 556-57 (claiming that no progress has been achieved in the last 200 years); Mordechai Kremnitzer, Is There a Rational Justification for Punishing an Accomplished Crime More Severely Than an Attempted Crime? A Comment on Prof. Dr. Björm Burkhardt's Paper, 4 B.Y.U. J. PUB. L. 81, 95 (1990) (raising doubts about whether any progress has been made since Platol).

${ }^{48}$ Most legal scholarship assumes, often without any empirical support, that individuals regard harm as relevant to criminal sanctioning. See, e.g., GEORGE FLETCHER, RETHINKING CRIMINAL LAW 483 (1978) (assuming that the reader would not regard himself to be fairly treated if the punishment for "culpably causing" harm and for having a "close call" were the same); 3 JAMES FITZJAMES STEPHEN, A HISTORY OF THE CRIMINAL LAW OF ENGLAND 311-12 (London, MacMillan 1883) ("[I]t gratifies a natural public feeling to choose out for punishment ... one who actually has caused great harm . ..."); Andrew Ashworth, Criminal Attempts and the Role of Resulting Harm Under the Code, and in the Common Law, 19 RUTGERS L.J. 725, 748 (1988) ("This approach is so ingrained in popular conceptions of responsibility . . . that it would be both unrealistic and unpractical to disregard."); Kadish, supra note 43, at 688-89 (stating that most people's "unexamined intuitions" run toward treating completed crimes more seriously than attempted crimes); Kremnitzer, supra note 47, at 81-82 (discussing the "gap" between the rational conclusion that attempts and completed crimes should be punished equally, and the popular notion that the two should be distinguished); Daniel M. Mandil, Note, Chance, Freedom and Criminal Liability, 87 CoLUM. L. REV. 125, 131 (1987) (assuming that "community sensibilities" would be to punish completed crimes more harshly than attempted crimes).

Some have challenged the claim that people tend to believe that punishment for attempts should be less severe than the punishment for completed crimes. Yoram Shachar believes that while such an intuition prevails on an instinctive level, it does not prevail when individuals reflect on the subject matter. See Shachar, supra note 44, at 23 ("[W] hile widely shared popular instinct is basically harm oriented, the Piagetian school of experimental psychologists has tapped a vein of harm-free judgment in human morality which is worthier as a model for official rule making, if public opinion is to be followed at all."). Empirical research seems, however, to verify that people in general believe that punishments for attempts should be lighter than the punishments for completed crimes. See PAUL H. ROBINSON \& JOHN M. DARLEX, JUSTICE, LIABILITY, AND BLAME: COMMUNITY VIEWS AND THE CRIMINAL LAW 27 (1995) ("In the view of our subjects, punishment ought not be imposed until a person has reached a point of dangerous proximity to completion of the offense. Further, the level of punishment for attempt ought to be significantly less than that for the completed offense.").

We believe that these intuitions are prevalent. The difference in the intuitions concerning the proper treatment of the perpetrator of an attempt and the perpetrator 
other hand, it seems that the culpability of the perpetrator of a completed crime does not differ from the culpability of the perpetrator of an attempt to commit the same crime if the failure is due to circumstances that are beyond the perpetrator's control. ${ }^{49}$

of a completed crime resides not merely in a judgment that the latter deserves harsher punishment or that the latter is more blameworthy. There is a qualitatively different attitude toward the two. Peter Winch beautifully articulated the difference when he pointed out that a man who commits a murder becomes a "murderer," while a man who attempts murder may become an "attempted murderer," but such a label has a different ring to it. See Peter Heath \& Peter Winch, Trying and Attempting, 45 PROCEEDINGS OF THE ARISTOTELIAN SOCIETY 209, 224 (Supp. 1971) ("That there are differences [between the labels 'murderer' and 'attempted murderer'] is brought out by the fact that it is perfectly possible to raise moral objections to any proposal legally to treat attempted murderers in the same way as murderers.").

${ }^{49} \mathrm{~A}$ failure to complete a crime is often described as an event that happened "merely" by chance or luck, rather than as one that is controlled by the agent. Hence, there is a powerful intuition that a completed crime and an attempt deserve the same punishment. See, e.g., ANDREW ASHWORTH, PRINCIPLES OF CRIMINAL LAW 396 (1991) (arguing that under the "just deserts" theory of criminal liability, a failed attempter and a successful criminal are "in terms of moral culpability, not materially different .... [T] [The difference in outcome is determined by chance rather than choice"); H.L.A. HART, Intention and Punishment, in PUNISHMENT AND RESPONSIBILITY 113, 131 (1968) ("Why should the accidental fate that an intended harmful outcome has not occurred be a ground for punishing less a criminal who may be equally dangerous and equally wicked?"); Ashworth, supra note 48, at 733 ("[T] he essence of a criminal attempt lies in the defendant's firm intention to commit the substantive offense, and the failure to achieve that harm is invariably attributable to factors such as luck, chance and misjudgment which do not significantly diminish culpability."); Burkhardt, supra note 47 , at $566-68$ (citing the ageless principle that assigning less severe punishment in occasions of fortuitous harmlessness cannot be squared with theories of culpability, and concluding that "[a] satisfactory solution . . . is not in sight"); R.A. Duff, Auctions, Lotteries, and the Punishment of Attempts, 9 LAW \& PHIL. 1, 1 (1990-91) ("If punishment should depend on desert, it should depend on culpability rather than on the actual causation of harm; on what the criminal wrongfully chose or tried to do, not on the chance matter of what harm he actually did."); Kadish, supra note 43 , at 689-90 (arguing that punishing attempts and completed crimes differently is tantamount to allocating punishment by lottery); David Lewis, The Punishment That Leaves Something to Chance, 18 PHIL. \& PUB. AFF. 53, 58 (1989) (recharacterizing the current system of harsher punishments for successful attempts as a covert penal lottery"); Richard Parker, Blame, Punishment, and the Role of Result, 21 AM. PHIL. Q. 269, 275 (1984) (arguing for a system of punishment where the riskiness of the conduct involved determines the appropriate sentence); J.C. Smith, The Element of Chance in Criminal Liability, 1971 CRIM. L. ReV. 63, 72 (arguing for the elimination of chance in liability determinations by treating attempts and completed crimes identically); Mandil, supra note 48 , at 140 (arguing that the existence of luck in human affairs provides an opportunity to examine the societal values underlying the differential treatment of attempted and completed crimes).

Many, however, have argued against the view that describes the failure of an attempt as an event that happened merely by chance or luck. These scholars have noted that "among the cases of success we will find more instances of careful planning and high-level performance than among the cases of failure" and therefore that the 
Different accusations are often directed against the doctrine of preparation, which establishes the exemption of early pre-crime activities from criminal liability. Drawing the distinction between attempt and preparation has proven to be difficult and very often arbitrary. ${ }^{50}$ The existence of such a distinction serves to decrease even further the sanctions on pre-crime activities. Thus, both the leniency of the treatment of attempt and the exemption for preparation can be interpreted as ways in which criminal law reduces the costs of pre-crime activities for criminals.

This Article suggests that the lenient treatment of attempt and preparation can be rationalized as an incentive scheme directed toward victims of crime. Thus, it is appropriate to begin with an analysis of the way in which attempt and preparation are treated under criminal law. Some of the existing theories that aim to justify the lenient treatment of pre-crime activities will then be critically explored. Given the nature of this investigation, the primary focus will be the treatment of attempt and preparation within economic analysis of law. Lastly, this Article will illustrate how, by endorsing a victim-centered perspective, one can arrive at a new explanation for why attempt and preparation ought to be punished less severely than completed crimes. More specifically, this Article will argue that punishing pre-crime activities less severely than completed crimes (as reflected both in the lenient treatment of attempt as well as the exemption of preparation from criminal liability) provides a global incentive for potential victims to reduce their investment in precautions. This Article will also suggest (although it does not provide conclusive proof) that such a reduction may be socially desirable given the incentives operating upon potential victims of crime to overinvest in precautions against crime.

failure of an attempt is an indicator of a lesser threat from the activity. Kremnitzer, supra note 47, at 87; see also Shachar, supra note 44, at 12 ("[T] he line between causing harm and nearly causing it is in reality often demarcated by differences in the perpetrator's own conduct. . . ."); Note, Why Do Criminal Attempts Fail? A New Defense, 70 YALE L.J. 160, 166 (1960) ("The much lower degree of punishment meted out to attempters represents, in part, an unarticulated recognition that the person who tries and fails is often less dangerous than the person who succeeds in his criminal purpose."). For an excellent discussion of the role of luck in the law, see Note, The Luck of the Law: Allusions to Fortuity in Legal Discourse, 102 HARV. L. REv. 1862, 1880-81 (1989) (arguing that events are characterized as fortuitous by the law when they are irrelevant to the disposition of the case and that this characterization is often conclusory in nature).

${ }^{50}$ See infra text accompanying notes 65-71. 


\section{B. The Treatment of Attempts in Criminal Law: A Brief Doctrinal Survey}

The doctrinal treatment of attempts is often regarded as "more intricate and difficult of comprehension than any other branch of the criminal law." ${ }^{11}$ This Section will not discuss all the intricate doctrinal questions concerning the treatment of attempts. ${ }^{52}$ Instead, it will discuss the actus reus and the mens rea required for an attempt.

\section{Actus Reus}

Both courts and scholars distinguish between attempt, which is punishable, and preparation, which is not punishable. Drawing the boundary between unpunishable preparation and punishable attempt has, however, haunted judges since the very criminalization of attempts. ${ }^{53}$ The variety of tests proposed by scholars and judgestests which purport to distinguish between mere preparation and fullfledged attempt-illustrates the complexity of the problem. ${ }^{54}$ The

${ }^{51}$ Hicks v. Commonwealth, 9 S.E. 1024, 1025 (Va. 1889).

52 Two important doctrinal problems will not be discussed in this Article: impossible attempts and the abandonment defense. Impossible attempts have sometimes been considered unpunishable. See MODEL PENAL CODE $§ 5.01 \mathrm{cmt}$. 3(a-b) (1985) (Impossibility) (noting that "the defense of impossibility . . . has sometimes been successful in attempt prosecutions"). Contemporary scholarship criticizes this view and many codes explicitly sanction impossible attempts. See id. ("Indeed, there is very little modern authority that supports a retention of the impossibility defense as such."). The abandonment defense has provided another important doctrinal debate occupying much of the scholarly writings on the subject of attempts. See, e.g., Paul R. Hoeber, The Abandonment Defense to Criminal Attempt and Other Problems of Temporal Individuation, 74 CAL. L. REv. 377, $381-82$ (1986) (exploring the abandonment defense and the modern doctrinal attitudes toward it).

${ }^{53}$ See Regina v. Eagleton, 169 Eng. Rep. 826, 835 (C.A. 1855) ("Some act is required, and we do not think that all acts toward committing a misdemeanor are indictable."); Donald Stuart, The Actus Reus in Attempts, 1970 CRIM. L. REV. 505, 505 ("Ever since...the test of remoteness [was introduced] in Eagleton (1855) controversy has raged over this question of what criterion should be used to determine" whether the accused's act is capable of incurring criminal responsibility although a full crime has not been committed (footnote omitted)).

${ }^{54}$ For a survey of the different tests, see MODEL PENAL CODE $\$ 5.01 \mathrm{cmt} 5$ (1985) (General Distinction Between Preparation and Attempt) (reviewing various tests "reflected in the case law when the Model Penal Code was being drafted"); Crocker, supra note 43, at 1077-93 (arguing "that liability should attach if there has been an attempt, per ordinary language, and the offender's actions have imposed a sufficient risk of what was intended coming about"); G.L. Peiris, Liability for Inchoate Crime in Commonwealth Law, 4 LEGAL STUD. 30, 41-54 (1984) ("The resolution of this dilemma is the object of a multiplicity of theoretical approaches, chief of which are the proximity and unequivocality doctrines developed in the decided cases and in current 
proximity test questions whether the defendant's act was sufficiently proximate to the intended crime..$^{55}$ Under this view, no act is indictable as an attempt unless it is a step toward the execution of the criminal purpose and is an act directly approximating or immediately connected with the commission of the offense that the person has in mind. ${ }^{56}$

The advocates of the proximity test provide a variety of tests as to the required degree of proximity. These tests include the "last proximate act" test $^{57}$ and the "dangerous proximity to success" test. ${ }^{58}$ Others have rejected the proximity test in favor of the equivocality test originally developed by John Salmond. ${ }^{59}$ Under the equivocality theory, an attempt is "an act of such a nature that it

academic writing."); Stuart, supra note 53, at 505-10 (critiquing the various existing tests under the equivocality and proximity doctrines and determining that "[n]one of the adopted tests is jurisprudentially indefensible").

${ }^{55}$ See GlanVille Wilitams, CRIMINal LAW 623 (2d ed. 1961) ("To be guilty of attempt, the accused must have progressed a sufficient distance along the intended path."). The test traces to Eagleton where it was formulated as follows: "Acts remotely leading towards the commission of the offence are not to be considered as attempts to commit it, but acts immediately connected with it are . . . " Eagleton, 169 Eng. Rep. at 835 .

${ }^{56}$ For a good description and critique of the test, see 1 RUSSELL ON CRIME 182, 184 (J.W. Cecil Turner ed., 12th ed. 1964) ("It is therefore suggested that a practical test for the actus reus in attempt is that the prosecution must prove that steps taken by the accused must have reached the point when they themselves clearly indicate what was the end towards which they were directed.").

${ }^{57}$ The test has been rejected by courts as well as by scholars as too rigid. See, e.g., Sizemore v. Commonwealth, 243 S.E.2d 212, 215-16 (Va. 1978) (holding that the commission of the last act was not necessary for a finding of attempted murder); see also MODEL PENAL CODE $\$ 5.01 \mathrm{cmt} .4$ (1985) ("Last Proximate Act") ("[T]here is general agreement that when the actor has done all that he believes necessary to commit the offense in question, he has committed an attempt.").

${ }^{58}$ Hyde v. United States, 225 U.S. 347, 388 (1912) (Holmes, J., dissenting); see also Commonwealth v. Kennedy, 48 N.E. 770, 770 (Mass. 1897) ("The act done must come pretty near to accomplishing that result before the law will notice it."); People v. Bracey, 360 N.E.2d 1094, 1097 (N.Y. 1977) (stating that the act must "carry the project forward within dangerous proximity to the criminal end to be attained" (quoting People v. Werblow, 148 N.E. 786, 789 (N.Y. 1925))); MODEL PENAL CODE $\$ 5.01 \mathrm{cmt}$. 5(b) (1985) (Dangerous Proximity Doctrine) ("The test is based on the assumption that ... until the actor's conduct becomes sufficiently dangerous, there is not adequate reason for deterring it.").

${ }^{59}$ See JOHN SALMOND, JURISPRUDENCE 404 (7th ed. 1924) ("No man can be safely punished for his guilty purposes, save so far as they have manifested themselves in overt acts which themselves proclaim his guilt."); see also MODEL PENAL CODE § 5.01 cmt. 5(f) (Res Ipsa Loquitor Test) ("[A]n attempt is committed when the actor's conduct unequivocally manifests an intent to commit a crime."); J.W. Cecil Turner, Attempts to Commit Crimes, 5 CAMBRIDGE L.J. 230, 237 (1933-35) (stating that acts "must be unequivocally referable to the commission of the specific crime"). 
is itself evidence of the criminal intent with which it is done. A criminal attempt bears criminal intent upon its face." ${ }^{60}$ The equivocality theory, although endorsed by some courts and legislatures, ${ }^{61}$ has received criticism from most scholars. ${ }^{62}$ Advocates of the probable desistance test have argued that a criminal attempt requires an act that, in the ordinary course of events, would result in the commission of a crime but for the intervention of an extraneous factor. ${ }^{63}$ The drafters of the MPC preferred to characterize attempt

${ }^{60}$ SALMOND, supra note 59, at 404 . Glanville Williams credits J.W. Cecil Turner for describing the test as follows:

"If the example may be permitted, it is as though a cinematograph film, which had so far depicted merely the accused person's acts without stating what was his intention, had been suddenly stopped, and the audience were asked to say to what end those acts were directed. If there is only one reasonable answer to this question then the accused has done what amounts to an 'attempt' to attain that end. If there is more than one reasonably possible answer, then the accused has not yet done enough."

WILlIAMS, supra note 55, at 629 (quoting J.W. Cecil Turner, in MODERN APPROACH TO Criminal LAW 280-81 (1945)).

61 The test enjoyed some popularity in other jurisdictions. The New Zealand Supreme Court employed a qualified version of the test in Campbell $\mathcal{F}^{\circ}$ Bradley $v$. Ward [1955] N.Z.L.R. 471, 474-75 (affirming the principle that conviction for a criminal attempt is only justified where the "act done with intent to commit [the crime] is in itself sufficient evidence of the intent"). Most commentators, however, have criticized the case. See, e.g., Williams, supra note 55, at 630-31 ("In short, the theory is of no help on the issue of proximity."); Stuart, supra note 53, at 508 ("There is little doubt that the wisest course for the courts would be to admit their error and disassociate themselves completely and frankly from the "equivocality test." "). Eventually, New Zealand abolished this standard through legislation. See Crimes Act, 1961, \$ 72(3) ("An act done or omitted with intent to commit an offence may constitute an attempt if it immediately or proximately connected with the intended offence, whether or not there was any act unequivocally showing the intent to commit the offence."). Some British courts have also endorsed this test. See, e.g., Davey v. Lee, 2 All E.R. 423, 425 (Q.B. 1967) (" $[\mathrm{T}]$ he actus reus necessary to constitute an attempt is complete ... [if its] doing . . . cannot reasonably be regarded as having any other purpose than the commission of the specific crime.").

${ }^{62}$ See, e.g., HALL, supra note 9 , at 581 (noting that "isolated behavior is always ambiguous so far as mens rea is concerned," and therefore that it cannot be predictive of intent); WILLIAMS, supra note 55, at 629-30 ("[A] strict application of the test would acquit many undoubted criminals."). Some exceptions, however, do exist. George Fletcher endorses the equivocality theory and regards it as supportive of his more general theory of "manifest criminality." See FLETCHER, supra note 48, at 144 ("[I]f an act is so equivocal that it does not generate apprehension, then it should not be subject to either private or public suppression.").

${ }^{63}$ See, e.g., United States v. Stephens, 12 F. 52, 56 (C.C.D. Or. 1882) ("[T]o constitute the attempt . . . there must have been ... an act done in pursuance of [a criminal] intention, that, apparently, in the usual course of events, would have resulted in [a crime], unless interrupted by extraneous circumstances . . . ."); State v. Schwarzbach, 86 A. 423, 424 (N.J. 1913) (noting that in an adultery case, an attempt 
as "an act or omission constituting a substantial step in a course of conduct planned to culminate in [the] commission of the crime." ${ }^{44}$ But while novel tests and sophisticated arguments were developed to rebut these tests, some scholars raised doubts about the feasibility and the desirability, of developing any test to distinguish between completed crimes and attempts. This skepticism arises from a suspicion as to whether a distinction between preparation and attempt can be drawn regardless of what is being attempted. Given that crimes are so radically different and diverse, it was argued that there is no way in which a useful characterization of conduct constituting an attempt could be made without specifying what the completed crime would be. ${ }^{65}$ Even the less skeptical voices who

consists of the performance of overt acts that, if unhindered, would result in a crime); State v. Brown, 95 N.C. 685 (1886) (holding that a conversation with an officer of the court and other related actions were not sufficient to constitute attempted jury tampering under a direct causation test); State v. Hurley, 64 A. 78, 79 (Vt. 1906) (holding that the procurement "of tools adapted to jail breaking" did not establish an attempt because the "act [stood] entirely unconnected with any further act looking to their use"); see also MODEL PENAL CODE \$5.01 cmt. 5(d) (1985) (Probable Desistance Test); Robert H. Skilton, The Mental Element in a Criminal Attempt, 3 U. PITT. L. REV. 181, 181 (1937) (stating that if an actor's intention, combined with an overt act, "fully consummated, would have resulted in consequences within the prohibitions of the criminal law, he may be guilty of a criminal attempt").

${ }^{64}$ MODEL PENAL CODE $\$ 5.01$ (1) (c) (1985).

${ }^{65}$ See Thurman W. Arnold, Criminal Attempts-The Rise and Fall of an Abstraction, 40 YALE L.J. 53, 57 (1930) ("These crimes are aimed at different kinds of conduct and to protect society against entirely different things."). Arnold endorsed a legal realist position and argued that no useful general tests could be developed for attempts as a general category. The claim that the boundary between preparation and attempt depends upon the crime attempted or on other facts particular to the case at hand is also supported by some judges and many traditional criminal law scholars. See, e.g., Commonwealth v. Kennedy, 48 N.E. 770, 771 (Mass. 1897) (noting the difficulty of balancing proximity to completion and expectation of success); FLETCHER, supra note 48 , at 141 ("[A] sensible approach requires that some attention be paid to the problems characteristic of different offenses."); OLIVER W. HOLMES, THE COMMON LAW 68-69 (1923); WILLIAMS, supra note 55, at 622 ("No exhaustive test can be stated: The only general rule is that mere 'preparation' for the crime is not enough-but this is only the proximity rule in negative form."); P.R. Glazebrook, Should We Have a Law of Attempted Crime?, 85 L.Q. REV. 28, 36 (1969) ("Why, then, should it be supposed that a single formula might... serve to identify the actus reus of such disparate offences as attempting to murder, attempting to obtain property by deception, and attempting to commit an act of gross indecency?"); Rollin M. Perkins, Criminal Attempt and Related Problems, 2 UCLA L. REv. 319, 327 (1955) ("Each case ... must be considered in light of all the facts involved."); Paul Kichyun Ryu, Contemporary Problems of Criminal Attempts, 32 N.Y.U. L. REV. 1170, 1175 (1957) ("Answers to the questions involving attempt cannot be derived by a purely logical method of deduction from a preconceived notion of 'attempt."); Francis Bowes Sayre, Criminal Attempts, 41 HARV. L. REV. 821, 845 (1928) ("The line between preparation and attempt, however, must at best depend largely upon the particular circumstances of each case . . .."). 
support maintaining the distinction between preparation and attempt concede that the characterization of the actus reus in attempt must remain imprecise and that the difference between preparation and attempt is a "difference in degree ... [rather than] in kind." ${ }^{\text {"6 }}$ The commentary of the MPC acknowledges the imprecision of its own guidelines $^{67}$ and adds a list specifying conduct that, as a matter of law, can be categorized as attempt. The drafters included the list in order to remedy some of the imprecision inherent in the doctrine. ${ }^{68}$

At the same time, other scholars challenged not merely the feasibility of drawing a precise distinction between preparation and attempt, but also the desirability of drawing such a distinction. The basis is that:

"The exact point at which [such preliminary steps] become criminal cannot, in the nature of things, be precisely ascertained, nor is it desirable that such a matter should be made the subject of great precision. There is more harm than good in telling people precisely how far they may go without risking punishment in the pursuit of an unlawful object." ${ }^{69}$

Skepticism concerning the feasibility or the desirability of drawing a precise boundary between preparation and attempt does not, however, overshadow the importance of drawing some boundaries. Most legal systems endorse a three-stage scheme under which

${ }^{66}$ HLALL, supra note 9, at 584. Holmes adopted the same position in Commonwealth v. Peaslee, 59 N.E. 55, 56 (Mass. 1901). There, Holmes said:

[P] reparation is not an attempt. But some preparations may amount to an attempt. It is a question of degree. If the preparation comes very near to the accomplishment of the act, the intent to complete it renders the crime so probable that the act will be a misdemeanor .... As was observed in a recent case, the degree of proximity held sufficient may vary with circumstances, including, among other things, the apprehension which the particular crime is calculated to excite.

Id. at 56.

Naturally, this position raises concerns of undue vagueness, which is inconsistent with the rule of law. See Ashworth, supra note 48, at 768 ("[T] he law of attempts fails to specify adequately the stage at which a person becomes liable to conviction.").

${ }^{67}$ See MODEL PENAL CODE $\S 5.01 \mathrm{cmt}$. 6(a) (1985) (Requirements of "Substantial Step" and Corroboration of Purpose) ("[T]he Code retains the element of imprecision found in most of the other approaches to the preparation-attempt problem.").

${ }_{63}^{63}$ See MODEL PENAL CODE $\$ 5.01$ explanatory note at 297 (1985) ("Subsection (2) elaborates on the preparation-attempt problem by indicating what is meant by the concept of 'substantial step ...."').

${ }^{69}$ Glazebrook, supra note 65 , at $35 \mathrm{n} .36$ (alteration in original) (quoting JAMES FITZJAMES STEPHEN, A GENERAL VIEW OF THE GRIMINAL LAW OF ENGLAND 83 (2d ed. 1890)). 
completed crimes are punished harshly, attempts are often punished less harshly, and preparation is not punished at all. ${ }^{70}$ The boundary between preparation and attempt, however, is imprecise. It is possible that its imprecision is inherent and cannot be remedied, ${ }^{71}$ but legislatures and courts can affect the position of the boundary between attempt and preparation by expanding the domain of one and shrinking the domain of the other. Policy considerations should determine whether such an increase or decrease in the scope of activities that are classified as preparation is desirable, even if drawing a precise line between preparation and attempt is neither feasible nor desirable. Thus, despite the imprecision of the test governing this issue, it is valuable to explore the effects of redrawing the boundaries between preparation and attempt. In particular, it is important to examine the effects of redrawing this boundary on the incentives operating on both criminals and victims.

\section{Mens Rea}

The mental element required in criminal attempts is that of actual intent to commit the actus reus of the crime attempted. ${ }^{72}$

${ }^{70}$ Theoretically, rather than dividing the criminal act into three discrete stages, one could increase the criminal sanction progressively in accordance with the stage of completion of the crime. This idea is hardly novel. In fact, it has been used in some legal systems. See Eugene Rankin Meehan, The Trying Problem of Criminal AttemptHistorical Perspectives, 14 U. BRITISH COLUMBIA L. REV. 137, 140 (1979) ("[I]n RomanDutch law, an attempt to commit a crime was itself punishable, no distinction being made between acts close to and remote from the 'target' crime, although the more proximate were the acts in question, the more severe was the punishment.").

Some provisions of the Federal Sentencing Guidelines can be regarded as implementing precisely such a scheme, where the degree of completion of a crime determines the severity of the sanction. Section 2A2.1.(b)(1) of the U.S. Sentencing Guidelines Manual specifies the punishment for attempted murder as follows: “(A) if the victim sustained permanent or life-threatening bodily injury, increase [the sanction] by 4 levels; (B) if the victim sustained serious bodily injury, increase by 2 levels; or (C) if the degree of injury is between that specified in subdivisions (A) and (B), increase by 3 levels." U.S. SENTENGING GUIDELINES MANUAL § 2A2.1 (b) (1) (1994).

A general rule that grades the sanctions progressively in accordance with the degree of completion of the offense cannot be easily administered due to the intractable difficulties in determining the degree of completion of the offense.

${ }^{71}$ See supra text accompanying notes 64-68.

${ }^{72}$ See WILLIAMS, supra note 55, at 618-21 (arguing that a conviction of attempt requires a demonstration of intent "to consummate the particular crime"); WILLIAMS, supra note 44, at 406-10 (explaining that the law of criminal attempt requires that one have actual intent to commit the underlying crime). The same rule applies in the United States; J.C. Smith, Two Problems in Criminal Attempts Re-Examined-I, 1962 CRIM. L. REv. 135,135 (" $[\mathrm{T}]$ he mens rea which must be proved to establish an attempt .. . 
Attempt requires intention as to the actus reus of the complete offense even if the complete offense is one that requires merely negligence, or recklessness, or strict liability. For example, a person who negligently attempts to drive a car with no brakes may not be convicted of attempt to drive a dangerous vehicle despite the fact that, had he succeeded, he would have been convicted of the completed act. This position has been criticized by some scholars, ${ }^{73}$ but it has been endorsed by the MPC. ${ }^{74}$ A debate surrounds the precise scope of this rule. ${ }^{75}$

is usually ... only an actual intention to cause the actus reus of the crime attempted ...."). See MODEL PENAL CODE \$ 5.01(1) (1985) (stating that to be guilty of a criminal attempt a person must "purposely engage[] in conduct that would constitute the crime if the attendant circumstances were as he believes them to be"). The explanatory notes to the Model Penal Code emphasize that the mens rea required in this section of the MPC is "designed to follow the conventional pattern of limiting the crime of attempt to purposive conduct." MODEL PENAL CODE $\$ 5.01 \mathrm{cmt} .2$ (1985) (Requirement of Purpose); see also Sayre, supra note 65, at 837-42 (arguing that an attempt requires intent as to all the elements of a crime because "[i]f none of the consequences which the defendant sought to achieve constitutes a crime, surely his unsuccessful efforts to achieve his object cannot constitute a criminal attempt").

${ }^{73}$ See HALL, supra note 9, at 597-98 (noting the ambiguity of the meaning of "intention" in several court cases); Paul H. Robinson, A Functional Analysis of Criminal Law, 88 Nw. U. L. REV. 857, 890-96 (1994) (arguing that "[n]o greater culpability than that required by the substantive offense ought to be required for attempt liability"); Smith, supra note 72, at 136-40 (arguing that intention need not extend to all the elements in the actus reus on a charge of attempt"); Donald Stuart, Mens Rea, Negligence and Attempts, 1968 CRIM. L. REV. 647, 655-62 (arguing that recklessness or negligence should be a sufficient mens rea to support an attempt conviction for a crime that requires a mens rea of recklessness or negligence, as appropriate).

74 See MODEL PENAL CODE $\$$ 5.01(1) (requiring that in addition to "acting with the kind of culpability otherwise required for commission of the crime," the actor must intend or believe that her conduct or omission will cause the commission of the crime or constitute a substantial step in its commission). Some common law systems seem to reject this principle. See Peiris, supra note 54, at $32-33$ (noting that courts in Canada, South Africa and Scotland do not require direct intent to establish attempt liability).

${ }^{75}$ It is clear that the requirement of purpose applies to the conduct of the perpetrator as well as the results. But many believe that the purpose need not encompass all of the circumstances included in the definition of the offense. See, e.g., ASHWORTH, supra note 49, at 400 (stating that "if two men set out to have sexual intercourse with two women, not caring whether they consent or not, it would be absurd if the one who achieved penetration was convicted of rape $e^{n}$ while the other who did not achieve penetration despite trying was acquitted of attempted rape); Peiris, supra note 54, at 34-35 ("[R]ecklessness as to circumstances surrounding the consequence supplies adequate mens rea in respect of a criminal attempt."); Skilton, supra note 63, at 183 ("The presence of an added circumstance ... do [es] not take away the fact that the defendant may be said to have intended certain criminal consequences . ... ."); Smith, supra note 72, at 136-40 ("[I]ntention need not extend to all the elements in the actus reus on a charge of attempt."); Glanville Williams, The 
In the following subsections, the traditional justifications for the law of attempts will be explored. We will demonstrate that the existing justifications rely exclusively on a perpetrator-centered perspective.

\section{Perpetrator-Centered Theories}

It has been established that criminal law has traditionally been lenient regarding pre-crime activities. This leniency has two primary manifestations. First, criminal law norms governing attempts often maintain a gap between the sanctions imposed on the perpetrators of attempts and the sanctions imposed on the perpetrators of completed crimes. Second, criminal law maintains a distinction between preparation and attempt, and exempts a broad range of precrime activities from criminal liability by labelling these activities "preparation." As mentioned, the relative leniency of criminal law toward pre-crime activities has often puzzled criminal law scholars as well as moral philosophers. ${ }^{76}$ Scholars differ radically in the result of their normative investigation. Despite the divergence in the views and perspectives of various scholars, however, a perpetrator-centered perspective has been consistently maintained.

\section{Nonutilitarian Theory}

Nonutilitarians have offered several theories that focus on aspects which are perpetrator-regarding. One branch of theories focuses on the arguably lesser culpability of the perpetrator of an attempt relative to the culpability of the perpetrator of a completed crime. ${ }^{77}$

Problem of Reckless Attempts, 1983 CRIM. L. REV. 365, 366-67, 374-75 ("[I]n the case of attempts ... it is enough that the defendant was reckless as to the circumstances."). But see Richard Buxton, Circumstances, Consequences and Attempted Rape, 1984 CRIM. L. REV. 25, 26-28 (arguing that "a statutory rule attributing a different mens rea in respect of circumstances and of consequences ... would lead to confusion"). For an attempt to provide a theoretical justification for distinguishing the conduct from the circumstances, see Arnold N. Enker, Mens Rea and Criminal Attempt, 1977 AM. B. FOUND. RES. J. 845, 866-78 (arguing that conduct is more likely to demonstrate intent than is the existence of external circumstances).

The narrow view under which intent applies to the conduct and the consequences, but not to the circumstances, has been endorsed by the MPC. See MODEL PENAL CODE $\S 5.01 \mathrm{cmt} .2$ (1985) (Requirement of Purpose) ("The requirement of purpose extends to the conduct of the actor and to the results that his conduct causes, but his purpose need not encompass all of the circumstances included in the formal definition of the substantive offense.").

${ }^{76}$ See supra notes $46-49$ and accompanying text.

${ }^{77}$ The general term used to describe these theories is moral luck. For a discussion 
Another branch of theories focuses on the liberties of the perpetrator, which arguably are infringed if attempts are punished. ${ }^{78}$ Yet another branch focuses on the opportunity of the perpetrator of an attempt to desist-an opportunity of which the perpetrator of the completed crime deprived herself. This opportunity to desist is necessary in order to provide the perpetrator with an opportunity to repent. ${ }^{79}$ All these nonutilitarian approaches share a common focus on the perpetrator of the crime and are therefore classified here as perpetrator-centered theories.

\section{Utilitarian Theory}

Utilitarian theories in general and economic analysis of law in particular also adhere to a perpetrator-based perspective. These theories maintain that the differential treatment of attempts is intended to provide incentives for the perpetrators of crime to desist and, hence, to prevent the harms. Under this view, the lesser punishment for an attempt is aimed to induce the perpetrator to abandon his plan and refrain from completing the crime. ${ }^{80}$ Again, this explanation concentrates on the effect of the sanction on the perpetrator of the crime. ${ }^{81}$ Let us explore in some detail the

of this theory by various authors, see MORAL LUCK (Daniel Statman ed., 1993).

${ }^{78}$ See generally Crocker, supra note 43, at 1059 (arguing against criminal liability based on the dangerousness or depravity of a criminal and arguing for criminal liability based on the extent of a criminal's "actual imposition upon his victim or society").

79 See Duff, supra note 49 , at 3435 ("[T] attempt gives the criminal ... a chance not just to repent his crime (a chance which the successful criminal has as well), but to give effect to that repentance by refraining from a further attempt to commit the crime.").

${ }^{80}$ Originally, the argument appeared in CESARE BECCARIA, ON CRIMES AND PuniShMENTS 68-69 (David Young trans., Hackett Publ'g Co. 1986) (1764). For effective critiques, see HART, supra note 49, at 130 ("[T] here seems [to be] no reason on any form of deterrent theory... for punishing the unsuccessful attempt less severely than the completed crime."); Lewis, supra note 49, at 53 ("[W] hat sense can we make of leniency toward a completed attempt-one that puts a victim at risk of harm, and fails only by luck to do actual harm?").

81 There is, however, one important exception to the perpetrator-centered perspective. Some utilitarians have pointed out that the victim of a crime has strong vengeful feelings toward the criminal, so that hurting the offender gives the victim something he values. Jeremy Bentham labelled these sentiments as "vindicative satisfaction." JEREMY BENTHAM, THE PRINCIPLES OF MORALS AND LEGISLATION $171 \mathrm{n} .1$ (Hafner Publ'g Co. 1961) (1781) ("Satisfaction thus administered to a party injured ... may be styled a vindictive satisfaction ...."). These sentiments would be particularly intense if the crime was successfully completed. See HART, supra note 49, at 131 ("Certainly the resentment felt by a victim actually injured is normally much greater than that felt by the intended victim ... ."); Ashworth, supra note 48, at 744 
traditional justifications for the differential treatment of attempts in the law and economics literature and establish the claim that these justifications are exclusively perpetrator-centered.

\section{Economic Theory}

Economic theories that examine the optimal punishment of attempts have been offered separately by Posner and Shavell. Posner argues that attempts ought to be punished in order to increase the expected cost of crime to criminals. ${ }^{82}$ In this way, additional deterrence is generated without making the punishment for the completed offense more severe. Posner supports the practice of punishing attempts less severely than completed crimes on a theory of "marginal deterrence," which suggests that once a criminal commits a punishable act, he should be provided with incentives to refrain from committing a more severe act. ${ }^{88}$ According to this theory, once a criminal places himself on the continuum of severity of criminal actions, marginal deterrence is required to deter him from moving along this continuum toward more severe acts. ${ }^{84}$ In

46 (" $[S]$ ince in attempted crimes there may not be an injured party, it would seem to follow that this element should be deducted from punishments for these crimes."). Many have resisted this argument by pointing out the illegitimacy of taking into account vengeful sentiments. See HART, supra note 49, at 131 ("[T] if this form of retributive [punishment] depends on the connexion between blame and resentment, whether the law should give effect to such a theory."); Kadish, supra note 43 , at $692-94$ ("[E]ven if . . the victim received a restorative amount of pleasure from the offender's suffering, it is not the morality of retributive punishment that would have been demonstrated, but the desirability of satisfying the vengeful feelings of the victim ...." (footnote omitted)). This argument is, under our classification scheme, a victim-centered one and is therefore an exception to the general tendency of criminal law to focus upon perpetrator-centered arguments.

${ }^{82}$ See Posner, supra note 16, at 1217-18 (providing a method for increasing levels of anticipated punishment costs without actually raising sanctions for completed crimes).

${ }^{83}$ The original theory of marginal deterrence in modern law and economics scholarship was developed by George Stigler. See Stigler, supra note 14. An excellent synthesis of this theory was advanced later by Shavell. See Steven Shavell, $A$ Note on Marginal Deterrence, 12 INT'L REV. L. \& ECON. 345-55 (1992) (pointing out that marginal deterrence requires graduated sanction only when enforcement is "general"); Shavell, Specific Versus General, supra note 14, at 1091-1101 (suggesting that where enforcement efforts are general, optimal sanctions rise in proportion to the harmfulness of the acts); see also Louis L. Wilde, Criminal Choice, Non-Monetary Sanctions, and Marginal Deterrence: A Normative Analysis, 12 INT'L REV. L. \& ECON. 33344 (1992) (discussing a model which illustrates that marginal deterrence is neither necessary nor sufficient in cases involving nontrivial criminal sanctions).

${ }^{84}$ Stigler's and Shavell's treatments of marginal deterrence intended to show why it is desirable to punish some offenses less severely than others; namely, why it would 
the context of attempts, marginal deterrence is required "to give offenders an incentive to change their minds at the last moment." That is, once the criminal act begins, it is desirable to offer the actor a reason not to complete it. Additionally, Posner argues, preparations to commit a crime (such as the announcement of one's intention to do so) should not be treated as attempts and should not be punished at all because of the lower probability that such preparations will actually lead to harm. ${ }^{86}$

Shavell, in a more systematic analysis, raises similar justifications for the treatment of attempts, suggesting that punishing attempts raises the expected sanction without increasing the magnitude of the sanction for the completed offense. ${ }^{87}$ If, under some constraints, the magnitude of the sanction for the completed crime cannot be raised, and if detection of attempted acts is a byproduct of the detection effort invested against completed acts, society can gain added deterrence "cheaply" by punishing the detected attempts. Invoking the marginal deterrence argument to justify a less severe punishment of attempts, Shavell points out that such treatment is useful only when the criminal can potentially reevaluate and abandon his act. In the case of attempts that were fully carried out yet failed due to chance, Shavell argues that marginal deterrence plays no role, and, as such, these attempts should be punished as severely as completed acts. ${ }^{88}$

be disadvantageous to punish every single offense with the maximum feasible sanction. See Shavell, supra note 83, at 351 (reiterating that marginal deterrence can be achieved also by graduating the probabilities of apprehension, not solely by graduated sanctions); Shavell, Specific Versus General, supra note 14, at 1090-1101 (demonstrating that graduated sanctions are desirable only when enforcement is general); Stigler, supra note 14, at 530-31 (stating the concern for marginal deterrence).

${ }^{85}$ Posner, supra note 16 , at 1217.

${ }^{85}$ See id. at 1218.

${ }^{87}$ See Shavell, supra note 17 , at 1249-52 (noting that the punishment of attempts can raise expectations of punishment without actually increasing the magnitude of overall punishment); Steven Shavell, Deterrence and the Punishment of Attempts, $19 \mathrm{~J}$. LEGAL STUD. 435, 436 (1990) [hereinafter Shavell, Deterrence] (suggesting that a partial justification for the punishment of attempts is that such punishment raises the probability of any sanctions being imposed, thus increasing deterrence).

${ }^{8}$ Shavell considered the possibility that offering less severe punishment for attempts that failed by chance would still generate marginal deterrence by preventing the criminal from attempting again and subjecting himself to the risk of an increased penalty for subsequent success. Shavell rejected this argument by arguing that marginal deterrence from renewed attempts can be provided, even if attempts are sanctioned as severely as completed acts, by raising the sanction with the number of attempts. See Shavell, Deterrence, supra note 87 , at 456 . 
Shavell stresses an additional "statistical" justification for punishing attempts less severely. He argues that when an attempt fails, it is indicative of the lesser danger that the act imposes. Since different acts may pose different degrees of dangerousness, and since this degree is not always evident, a failed attempt may be regarded as evidence that the act was, $a$ priori, less likely to result in harm; failed attempts should therefore be punished less severely. ${ }^{89}$

Although many economists endorse the Posner-Shavell treatment of attempts, ${ }^{90}$ the theory is not without its difficulties. Its marginal deterrence application justifies the lenient treatment of attempts as providing incentives for rational criminals to "change their minds" and abandon a plan that they have already begun to pursue. One may wonder why rational individuals would even begin the pursuit of a crime if they expect to change their minds in the process. If the incremental sanction imposed on completed acts is sufficient to generate marginal deterrence, why does it not generate full deterrence and prevent the initiation of pre-crime activities? After all, a criminal who commits an attempt intends it to succeed, and takes into account the sanction for completed acts. If that does not deter him, why would the same sanction deter him when he has already initiated the act and has only to decide whether to finalize it? Unless the criminal learns new information that leads him to reevaluate the desirability of completing the crime, there is no reason to expect marginal deterrence to operate upon him. The very same assumption that underlies the marginal deterrence theory-the assumption of rational behavior-raises difficulty in the consistent application of the theory. ${ }^{91}$

Additional difficulties arise with respect to the statistical justification of attempts. In some cases, the failure of the attempt does indeed provide an indication of its lesser degree of dangerousness. But many attempts fail strictly due to chance, and do not reflect the lesser dangerousness of the particular perpetrator. In such cases, there is no statistical basis for lenient treatment. ${ }^{92}$

${ }^{89}$ See also supra note 48 and accompanying text.

${ }^{90}$ See, e.g., Samuel Kramer, Comment, An Economic Analysis of Criminal Attempt: Marginal Deterrence and the Optimal Structure of Sanctions, $81 \mathrm{~J}$. CRIM. L. \& CRIMINOLOGY 398, 415-16 (1990-91) (suggesting that the punishment for attempts should be scaled according to the criminal's private benefit instead of the degree of social harm inflicted by her acts).

${ }^{91}$ For further discussion of this difficulty, see Shavell, Deterrence, supra note 87 , at 455-56.

${ }^{92}$ See id. at 452-54 (discussing this objection and concluding that the statistical 
Further, courts may, and do, apply inference methods other than statistics to assess the dangerousness of an act, in which case the statistical treatment becomes redundant.

Aside from the analytical difficulties of the Posner-Shavell approach, its perspective is limited because it is strictly perpetratorcentered. Posner and Shavell focus exclusively on the incentives guiding the perpetrators of crime and (as in the statistical justification) on how courts can distinguish ex post between different types of perpetrators. In light of this unilateral dimension, and the evident difficulties it raises, the next Section of this Article will explore a different economic understanding of the law of attempt. It will argue that the treatment of attempts can be rationalized by a victimcentered perspective. This approach does not contradict or conflict with the perpetrator-centered approach. In fact, the victim-centered approach shares the rationality and efficiency premises of the PosnerShavell approach and complements it to form a broader and more applicable set of justifications for the criminal law's treatment of attempts.

\section{Punishing Pre-Crime Activities: A Victim-Centered Perspective}

Leniency toward pre-crime activities is a mechanism that provides global incentives for potential victims to reduce their investment in precautions. In defending this claim two aspects of the legal treatment of pre-crime activities will be addressed: the gap between the sanctions for attempts and completed crimes, and the reluctance of criminal law to punish preparation. Both principles are subtle mechanisms that primarily reduce the expected costs of punishment for criminals who target overly cautious victims. Consequently, both principles provide incentives for criminals to shift the aim of their activity from less cautious victims to more cautious ones and thereby provide incentives for potential victims to reduce their investment in precautions.

Providing victims with incentives to reduce their precautions is desirable in situations in which victims are more likely to overinvest. Some concerns leading to the conclusion that victims indeed overinvest in precautions will be highlighted in this Section. However, the two facets of the analysis, the positive and the norma-

justification of the lenient treatment of attempts is justified only if the attempt was deliberately abandoned by the perpetrator, and not if the attempt was interrupted; only in the former case does a failed attempt indicate a lesser dangerousness). 
tive, are independent of each other. One may dispute the Article's normative claim that victims ought to be given incentives to reduce their investment in precaution, while at the same time embrace the positive characterization of the incentive effects of the law of attempt.

\section{The Incentive Effects of Sanctioning Pre-Crime Activities}

\section{a. Attempts Versus Completed Acts}

Precautions against crime taken by potential victims reduce the chances of successful completion of the crime either by increasing the chances that the perpetrator will not complete the activities he plans to commit, or by increasing the chances that, even if the perpetrator completes his plan, the desired consequences of the plan will not be realized. Consequently, crimes directed against more cautious victims are more likely to fail and end up being classified as attempts and punished accordingly. The more potential victims invest in precautions, the more likely they are to be the victims of unsuccessful attempts rather than victims of completed crimes.

The very same conclusion is grounded in an additional, independent observation. Precautions taken by potential victims of crime force potential criminals to go through a longer sequence of precrime activities. The longer sequence of pre-crime activities exposes the perpetrator to a greater risk of being interrupted before the completion of the crime. Hence, a crime directed against a more cautious victim is more likely to wind up being classified as an attempt than a crime directed against a less cautious victim.

These findings imply that criminals targeting highly cautious victims are more likely to be influenced by sanctions imposed for attempts than criminals operating against less cautious victims because it is the former type of criminal whose actions are likely to result in unsuccessful attempts. As the sanction for attempts decreases relative to the sanction for completed acts, the expected cost of sanctions facing criminals decreases, regardless of the type of victim they target. This expected cost of sanction decreases more if the criminal targets an overly cautious victim. Consequently, as the sanction for attempts decreases, cautious victims become more attractive targets. Thus, some criminals are likely, under a rule that exculpates or mitigates the sanctions for attempts, to substitute their targets and choose to act against more cautious victims, rather than against less cautious ones. 
The following hypothetical example should illustrate the incentive effects that mitigated sanctions have on criminals. Suppose victims can take one of two levels of precautions, "high" or "low." If the low level of precaution is taken, the criminal's probability of success is .75 (the probability of failure is .25), and if the high level of precaution is taken, the criminal's probability of success is .25 (the probability of failure is .75). Also assume that the probability of detecting and sanctioning a criminal is .4 , independent of whether the act succeeds. ${ }^{93}$

If the criminal commits a completed crime and is apprehended, his sanction is assumed to be 100. To illustrate the effect of a mitigated treatment of attempts, let us see how the criminal's incentives change with the sanction for a failed attempt. Denote the sanction for an attempt by $S$. If the criminal targets a low-precaution victim, his expected sanction is:

$$
\begin{gathered}
(.75 \times .4 \times 100)+(.25 \times .4 \times \mathrm{S}) \\
=30+(.1 \times \mathrm{S}) .
\end{gathered}
$$

If, however, the criminal targets a high-precaution victim, his expected sanction is:

$$
\begin{gathered}
(.25 \times .4 \times 100)+(.75 \times .4 \times \mathrm{S}) \\
=10+(.3 \times \mathrm{S})
\end{gathered}
$$

We can graph the criminal's expected sanction as a function of $\mathrm{S}$ :

Figure 1:

Expected Sanction

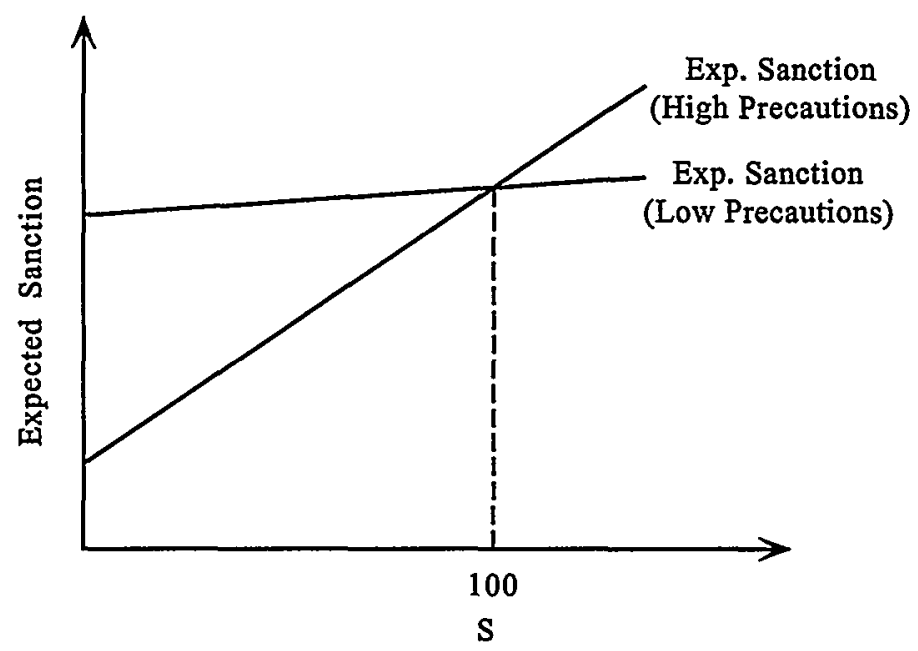

${ }^{93}$ It is plausible that the probability of detecting and sanctioning attempts is different than that of completed crimes. This possibility is examined infra Part IV.D.2. 
The two lines in Figure I represent the expected sanction costs of targeting high-precaution and low-precaution victims. We see that if $S<100$, the expected sanction is higher when targeting a lowprecaution victim than when targeting a high-precaution victim. In this case, the criminal will have an incentive to act against a highprecaution victim, and benefit from a lower expected sanction. As the sanction for attempts, S, decreases, the gap between the expected sanctions for targeting the two types of victims increases, and consequently, high-precaution victims become more attractive. Conversely, if $S>100$, the expected sanction will be lower when targeting a low-precaution victim, and the criminal will have an increased incentive to act against such victims.

To illustrate this point further, consider the choice between four possible sanctions for attempts. In Case 1 , attempts are punished the same as completed crimes-a sanction of 100 . In Case II, attempts are treated more leniently, and receive half the sanction-50. In Case III, attempts carry a sanction of 25 , and Case IV involves the ultimate leniency toward attempts-a sanction of 0 . The following table summarizes the expected sanctions the criminal faces:

\section{TABLE I}

Case I Case II Case III Case IV

Expected Sanction if Precautions are "Low"

Expected Sanction if Precautions are "High"

\begin{tabular}{|c|c|c|c|}
\hline 40 & 35 & 32.5 & 30 \\
\hline 40 & 25 & 17.5 & 10 \\
\hline
\end{tabular}

As criminal law moves toward a more lenient treatment of attempts, the expected sanction falls for attempts against both high and low-precaution victims. ${ }^{94}$ But, as the table demonstrates, the sanction falls more sharply if the precaution level is high. In the extreme, if attempts are not punished at all (Case IV), the difference

94 To understand how the expected sanctions are calculated, take the row of "Low Precautions" as an example. We have calculated that the expected sanction in this row is $30+(.1 \times S)$. When $S=100$ (Case $I)$, the expected sanction will be $30+(.1 \times$ $100)=40$. When $S=50$ (Case II), the expected sanction will be $30+(.1 \times 50)=35$, etc. Similarly, for the "High Precautions" row, we use the formula of $10+(.3 \times \mathrm{S})$, so that when, for example, $\mathrm{S}=25$ (Case III), the expected sanction is $10+(.3 \times 25)$ $=17.5$. 
in the expected sanction is 20 (an expected sanction of 30 if the precaution level is low, 10 if high). Thus, as the treatment of attempts becomes more lenient, high levels of precaution lose more of their deterrent factor.

The sanction for attempts can also be raised above the sanction for completed crimes to generate the opposite effect. Figure I demonstrates that as $S$ increases above 100 , the expected sanction for targeting high-precaution victims increases relative to the expected sanction for targeting low-precaution victims. This "super-punitive" treatment of attempts may be difficult to justify on other grounds, but it does provide the incentive for victims to better protect themselves.

The argument presented above suggests that a high level of precaution loses some of its benefit for the victims when the law's treatment of attempts becomes lenient. To be sure, there are benefits to a high level of precaution that victims may still enjoy. For one, the reduced likelihood that the crime will be successfully completed is perhaps the most significant benefit of setting a high level of precaution, and this benefit is not affected by a lenient treatment of attempts. Thus, from the criminal's point of view, targeting a high-precaution victim has an advantage relative to targeting low-precaution victims, namely the lower-expected sanction (and perhaps also a higher "prize," if precautions are positively correlated with victims' wealth). Nevertheless, targeting highprecaution victims has a disadvantage-the lower probability of success. The ultimate choice, therefore, depends on many ad hoc parameters that are outside the scope of this Article, including the observability of precautions and the wealth of the victim. ${ }^{95}$ This Article's claim ignores many important benefits that victims enjoy from setting high levels of precautions, and it rests on the analysis of merely one benefit that arises from precautions-the deterrent effect of the expected sanction. It concludes that, as the sanction for attempts decreases, the deterrent effect of precautions subsides, and, thus, the relative attractiveness of the high-precaution victim increases. Overall, the more lenient the treatment of attempts, the more likely are criminals to target high-precaution victims.

${ }^{95}$ Another element that affects a criminal's choice between high-precaution and low-precaution victims is the probability of being detected, which may vary depending on whether the crime succeeds or fails. An analysis of this effect is presented infra Part IV.D.2. 
In light of this effect on criminals' choice of victims, the victims' incentives to engage in precautions can now be examined. Under a system that mitigates the sanctions for attempts, victims will find it less profitable to engage in a high level of precaution relative to a system that punishes attempts and completed acts equally. Establishing a high level of precaution is less profitable because the precautions will cause more criminal acts to fail and, thus, be classified as attempts. As argued, the reduced sanction for attempts raises criminals' tendency to select highly cautious victims. Thus, victims who choose a high level of precaution will become more appealing targets if attempts are sanctioned leniently. Consequently, victims will have an incentive to reduce their precaution level. As the example above demonstrates, victims' incentives to choose a low level of precaution are augmented when attempts are treated more leniently. By choosing a low level of precaution, victims forgo some of the preventive benefit, but instead succeed to be protected by a relatively higher expected sanction, that is, to deter more criminals from targeting them.

In the analysis introduced above, the law of attempts provides global incentives to reduce victims' precautions. These incentives are global because they span many types of victim behavior and across many types of criminal offenses. Any type of activity by victims that reduces the chance that a crime will succeed-protecting one's home, carrying defensive weapons, monitoring one's agents, etc.will be influenced by this incentive device.

Lastly, it should be noted that the victim-centered perspective holds regardless of the content of the law. Different regimes may treat criminal attempts differently-some more leniently, others more strictly. Each will affect the victims' incentives differently, with the stricter regimes leading to higher levels of precaution. What this positive analysis demonstrates is that by focusing on victims' incentives, the interplay between the sanctioning policy and the levels of precaution can be determined. Before turning to the normative evaluation of the different treatments of attempt, another positive aspect of the law of pre-crime activities will be examinedthe incentive effects of distinguishing between preparation and attempt. 


\section{b. Attempt Versus Preparation}

Part IV.B surveyed one of the more intricate doctrinal problems in criminal law, namely, the elusive boundaries between preparation and attempt. While it was argued that drawing a precise boundary between preparation and attempt is not manageable, it was nonetheless maintained that criminal law norms can expand the stage of unpunishable preparation and, hence, diminish the stage of punishable attempt or, alternatively, diminish the stage of preparation and expand the stage of attempt. This Section will argue that the choice to expand one stage at the expense of the other affects victims' investments in precautions.

The activities preceding crimes that are directed against overly cautious victims are longer and more complex than the activities preceding crimes directed against less cautious victims. The risk that pre-crime activities targeting cautious victims will be interrupted (and that the perpetrator will be subject to the sanctions that the legal system imposes upon these activities) is therefore larger. Criminals who target cautious victims are affected more significantly by the sanctions imposed by the criminal system on pre-crime activities.

Expanding the unpunishable stage for pre-crime activities at the expense of the punishable stage reduces the expected cost of sanctions facing criminals, regardless of the type of victims they target. But this expected cost of sanctions decreases more if the criminals target the more cautious victims. Thus, the longer the unpunishable preparation stage, the greater the incentives for criminals to target cautious victims. These dispositions on the part of criminals influence, in turn, the investment in precautions by potential victims of crime. For reasons similar to those discussed above, the longer the unpunishable stage of pre-crime activities, the smaller the investment in precautions by potential victims. The increased disposition of criminals to target cautious victims will induce potential victims to reduce their investment in precautions.

\section{c. Summary}

Modifying the sanctions for attempts and modifying the boundaries between preparation and attempt can be described as legal mechanisms aimed at altering the expected costs of pre-crime activities. Criminal law can treat pre-crime activities harshly (by increasing the sanctions on attempts or by expanding the scope of attempts at the expense of preparation) or it can treat pre-crime 
activities leniently (by reducing the sanctions for attempts or by expanding preparation at the expense of attempts).

Subsections $a$ and $b$ show that criminals who target overly cautious victims are more sensitive to the sanctions that govern precrime activities. Consequently, by modifying the sanctions for precrime activities (either by modifying the sanctions for attempts, or by modifying the boundaries between attempt and preparation) the law influences discriminately the expected costs imposed upon criminals who target highly cautious victims and those who target less cautious victims. Reducing the sanctions for pre-crime activity leads to a greater reduction of expected costs for criminals who target highly cautious victims. This provides, in turn, global incentives for potential victims to reduce their investments in precautions.

Finally, the law of pre-crime activities could, in a hypothetical criminal law regime, provide local, rather than global, incentives to reduce precautions. The law could treat pre-crime activities discriminately, according to the specific crime attempted or the specific precautions applied by victims. For example, rather than discounting penalties for attempts uniformly, the law could differentiate the discounts in accordance with the particular offense. This approach would have the same systematic effect on victims' behavior but would offer greater flexibility in controlling specific types of investments in precautions.

\section{Extension: Differentiated Probability of Detection}

One simplifying assumption made thus far is that the probability of detection is independent of whether the criminal act succeeds. The ensuing analysis takes a closer look at the role of the probability of detection. Obviously, the probability of detecting and sanctioning attempts may be different from the probability of detecting and sanctioning completed crimes. For one, it may be that attempts are harder to detect, either because they often go unnoticed, or because the absence of physical harm reduces the readiness of victims and witnesses to report the acts. Additionally, the prosecution may be less likely to pursue a case without actual harm; a detected attempt may thus end up unsanctioned. The opposite may also be true: if a crime fails due to some precautionary measure, this same measure may lead simultaneously to the detection of the criminal (e.g., alarm, sirens). Or, a completed crime may eliminate the witness or the evidence (as in the case of murder or fire), in which case it will be easier to detect an attempt. Thus, we need to consider two possibili- 
ties: first, whether there is a lower probability of detecting attempts, and then whether there is a higher probability of detecting attempts compared to completed crimes.

\section{a. Lower Probability of Detecting Attempts}

To examine how the lower probability for detecting attempts affects the incentives to target high-versus low-precaution victims, we shall return to the numerical example presented above. Recall that the sanction for a completed crime is 100 , the sanction for an attempt is $S$, the probability of success is .75 if targeting a lowprecaution victim, and .25 if targeting a high-precaution victim. Assume now that the probability of detection depends on whether the act succeeds. Specifically, the probability of detection continues to be .4 if the criminal act fails and remains merely an attempt, but it is higher-assumed to be .6-if the act succeeds. Under these assumptions, the expected sanction for targeting a high-precaution victim is:

$$
\begin{gathered}
(.25 \times .6 \times 100)+(.75 \times .4 \times \mathrm{S}) \\
=15+(.3 \times \mathrm{S}),
\end{gathered}
$$

and the expected sanction for targeting a low-precaution victim is:

$$
\begin{gathered}
(.75 \times .6 \times 100)+(.25 \times .4 \times \mathrm{S}) \\
=45+(.1 \times \mathrm{S}) .
\end{gathered}
$$

Comparing the two expected sanction functions, one can establish that the expected sanction for targeting high-precaution victims is higher than the expected sanction for targeting lowprecaution victims whenever $S<150$. Namely, at $S=100$ (i.e., when the sancrion for attempt equals the sanction for completed act), high-precaution victims involve a lower expected sanction and are relatively more desirable targets. Recall that when we assumed that the probabilities of detection were the same for attempts and completed acts, the critical value of $S$ (the value under which the expected sanction becomes smaller for high-precaution victims) was 100 , whereas now it is 150 . This difference implies that the lower probability of detecting attempts is itself a force that makes highprecaution victims more attractive to criminals. With the greater probability of failure, there is a smaller expected sanction.

Hence, even without differentiating the sanction for attempts from completed crimes, there are already some incentives for criminals to prefer high-precaution victims. As the sanction for attempt becomes more lenient, these incentives are augmented. The 
lenient treatment of attempts operates on criminals' incentives in the same direction as the lower probability of detecting attempts.

\section{b. Higher Probability of Detecting Attempts}

Assume now the opposite case, that attempts are more easily detected than completed crimes. Specifically, assume in the above example that attempts are detected with probability .4, whereas compete crimes are detected with only .2 chance. Calculating the criminals' expected sanction in a similar manner as above, we find that the expected sanction for targeting a high-precaution victim is $5+(.3 \times S)$, and the expected sanction for targeting a low precaution victim is $15+(.1 \times \mathrm{S})$.

Comparing the two functions, we can establish that whenever $S<50$, the expected sanction is higher when targeting a low-precaution victim. But when $S>50$, and in particular when $50<S<100$, that is, still less than the sanction for the completed act, the expected sanction is higher when targeting a high-precaution victim. In comparison to the case in which the probability of detection was the same for attempts and completed acts (in which case it was sufficient to set $S<100$ to generate a higher expected sanction for highprecaution victims) we now need to treat attempts even more leniently in order to generate the criminal's preference toward highprecaution victims. In fact, for any $S$ at all, the relative desirability of low-precaution victims is diminished. Thus, the higher probability for detecting attempts is a consideration that makes high-precaution victims less attractive to criminals: with the greater probability of failure there is a higher probability of detection, and higher expected sanction.

Hence, without differentiating the sanction for attempts from completed crimes, criminals would strictly prefer low-precaution victims: not only are they more likely to succeed with the act, but they also benefit from a smaller probability of detection. Still, lenient sanctions for attempt can reverse this trend. But now the degree of leniency must be greater. The discount in the penalty for attempts must be more significant if it is to make high-precaution victims more desirable targets. 


\section{The Efficiency of the Law of Pre-Crime Activities}

This Article has argued that treating pre-crime activities leniently, as most legal systems do, leads victims to reduce their investments in precautions. Is this a desirable outcome?

In Part II, the distortions of victims' choices of precautions were examined. The conclusion was ambiguous. Conflicting forces drive victims to take either too many or too few precautions, and the direction of the distortion cannot clearly be determined. Absent a thorough empirical investigation, conjecture is speculative, based on common sense and anecdotal evidence.

We believe that in a large set of situations, the dominant source of distortion of victims' incentives is the diversion of crime, which leads victims to take excessive precautions. Take property crimes for example. Many types of victims' precautions, particularly those that operate as protective measures to reduce the chances of harm to the victims, merely divert crime to other scenes. If a victim builds a fence around her house, the burglar will strike elsewhere; if a victim installs a car antitheft device, the car thief will turn to another target; if a victim carries only a small amount of money, the robber will rob again in the hopes of recovering a larger amount. If a diversion of crime is the result of victims' precautions, the level of precaution will be socially excessive. ${ }^{96}$ Thus, inasmuch as precautionary activities are observable to criminals, the concern exists that an overinvestment in precautions will arise. ${ }^{97}$

Similar reasoning applies to other types of offenses, including violent crimes. If one victim's precautions merely transfer the crime to another victim, there is no net social gain from these precautions, and they ought to be discouraged. Similarly, if victims refrain from various types of everyday activity in order to limit their exposure to random crime, the amount of crime does not necessarily decrease, and society bears the cost of this suppressed activity. Thus, precaution against violent crime is another instance in which victims should be driven to engage in a lesser degree of protection.

In support of these theoretical conjectures regarding the level of precaution, one need only measure the size of annual spending on precautionary measures in the United States. In a study looking at

${ }^{96}$ See supra Part II.A (discussing overinvestment in precautions).

${ }^{97} \mathrm{Cf}$. Shavell, supra note 17 , at 1232 (asserting that "because nonmonetary sanctions are socially costly to impose, it is best for society to threaten to impose the sanctions only where parties can probably successfully be deterred from acting undesirably"). 
the fiscal year 1985, economists estimated that victims' expenditures made toward limiting physical access to their property was over $\$ 160$ billion. ${ }^{98}$ Domestic security expenditures by the private sector exceeded public military spending in that year. ${ }^{99}$ The high magnitude of these figures is alarming. It implies, we argue, that a social problem of overinvestment in precautions exists. In light of this problem, a global mechanism to reduce spending, such as the one herein examined, gains merit. Hence, one may claim that it makes economic sense to treat attempts leniently, thereby providing victims with global incentives to reduce their overall levels of precaution.

\section{Objections}

\section{a. The Limits of the Mechanism}

We argue that treating pre-crime activities more leniently leads criminals to target more cautious victims. Clearly, this does not mean that criminals will exclusively target highly cautious victims. A problem arises, however, in determining the effect on victims who tend to take intermediate levels of precautions. ${ }^{100}$

To illustrate this problem, consider the following example. Denote a rule that treats pre-crime activities leniently as "LR" and a rule which treats pre-crime activities harshly, "HR." Assume that there are three types of potential victims: type A victims who take low levels of precaution, type B who take intermediate levels of precaution, and type $C$ victims who are highly cautious. Under the HR regime, some criminals target $A$, some target $B$, and some target C. What happens if we move to the LR regime? Because of the lower expected sanctions, some of the criminals previously targeting type $A$ victims will shift to type $B$ victims or to type $C$ victims, and some of the criminals targeting type $B$ victims will shift to type $G$ victims. It is unclear whether type $B$ victims will be worse off under LR than under HR. Thus, we cannot determine in the abstract how

${ }^{98}$ See Laband \& Sophocleus, supra note 5, at 962-63. This study estimated the total expenditures on transfer activities (including government enforcement, insurance, and litigation) to be in excess of $\$ 400$ billion. See id. at 962 . The victims' precautions category, which totalled more than $\$ 160$ billion, includes the estimated cost of locks, alarms and guards for both residences and businesses. See id. at 962-63; see also Philipson \& Posner, supra note 5, at 406-07 (listing common precautions taken by potential victims).

${ }_{99}$ See Laband \& Sophocleus, supra note 5, at 965 (reporting military expenditures of approximately $\$ 226$ billion in 1985 ).

${ }_{100}$ We are grateful to Mike Otsuka for this argument. 
the rule will affect the victims taking intermediate levels of precaution.

This analytical shortcoming of the proposed approach does not, however, lead to the unravelling of the incentive mechanism. One should keep in mind that the social objective is not necessarily to monitor each victim's actions perfectly, but to implement more efficient macro levels of precautions. A successful regime is one that will lead to an overall reduction in spending on precautions, even if some victims are not affected (or adversely affected) by the general trend. Thus, even if type B victims do not reduce their still excessive precautions, the $L R$ regime may be desirable given its overall effect.

\section{b. Is Criminal Law the Proper Tool?}

Under the victim-centered perspective, criminal law can be designed to affect the incentives operating upon victims in their decisions to take precautions against crime. Thus, the addressees of criminal law injunctions are, under this analysis, not merely potential criminals, but also potential victims. This approach expands both the range of individuals who are depicted as the addressees of criminal law injunctions, as well as the set of activities the criminal law aims to influence.

This expansion raises difficult questions concerning the proper role and boundaries of criminal law. If criminal law can be used to provide potential victims with incentives to take precautions, why can it not be used in the same manner to provide incentives for potential victims to be good citizens in other sectors of life? Can one induce individuals to contribute to charity or to pay their debts or alimony on time by manipulating the criminal sanctions that are imposed for crimes committed against these individuals? If such a proposal seems pernicious, why is it legitimate to use the criminal law to induce potential victims to take efficient precautions against crime? Specifically, which categories of behavior should society induce on the part of potential victims through the mechanism of differentiating the sanctions imposed upon crimes directed against these victims?

Admittedly, the logic of this Article's approach fits any kind of victim behavior. But this "mechanical" conformity does not present the whole picture. There are other factors that ought to determine when an applicable incentive mechanism should be utilized. Specifically, it may be legitimate to use differentiated sanctions to 
monitor victims' precautions, while it may be illegitimate to use it to monitor other types of non-virtuous behavior.

A full exploration of the role and boundaries of the criminal law, and of the behavior it can legitimately induce, is beyond the scope of this Article. Let us, however, provide several reasons that support the claim that inducing individuals to take efficient precautions is within the sphere of legitimate criminal law application.

First, by regulating the behavior of potential victims, criminal law does what other areas of law have long been expected to do. ${ }^{101}$ Contract law, through doctrines of reliance and mitigation, issues directives to the victims of breached contracts as well as to those who have committed breaches. ${ }^{102}$ Similarly, tort law, through contributory negligence doctrines, induces action not only by potential tortfeasors, but also by the victims of torts. ${ }^{103}$ Criminal law, on the other hand, is ordinarily regarded as an exception in this respect, but only because its rhetoric presupposes an exclusively perpetrator-based perspective.

Second, there seems to be an inherent difference between an investment in precautions and other activities undertaken by victims. This difference suggests that the only type of victim behavior the criminal law can effectively induce through the mechanisms analyzed above is an investment in precautions. Criminal law can induce potential victims to take efficient precautions because of its influence

${ }^{101}$ See Cooter, supra note 3, at 3-29 (discussing how the law encourages precautions in torts, contracts, and property).

${ }^{102}$ For a discussion of various types of victims' incentives, see $i d$. at 44 (suggesting a symmetry between the roles of injurers and victims in preventing losses). On victims' incentives to make reliance investments, see Steven Shavell, Damage Measures for Breach of Contract, 11 BELL J. ECON. 466, 467-72 (1980) (discussing the use of damage measures to influence the behavior of parties who have entered into a contractual relationship); William P. Rogerson, Efficient Reliance and Damage Measures for Breach of Contract, 15 RAND J. ECON. 39 (1984) (extending Shavell's analysis to focus strictly on reliance decisions); Steven Shavell, The Design of Contracts and Remedies for Breach, 99 Q.J. ECON. 121 (1984) (asserting that contingent contract terms, remedies for breach, and renegotiation all "induce parties to behave approximately as they would under detailed contracts"). On victims' incentives to reveal information, see Ian Ayres \& Robert Gertner, Filling Gaps in Incomplete Contracts, 99 YALE L.J. 87 (1989) (discussing the use of penalty defaults to induce potential breach victims to contract around default provisions); Lucian A. Bebchuk \& Steven Shavell, Information and the Scope of Liability for Breach of Contract: The Rule of Hadley v. Baxendale, 7 J.L. ECON. \& ORG. 284, 285 (1991) (arguing that efficient default rules should mimic the parties' will, or make the option of opting-out cheap).

${ }^{103}$ See STEVEN SHAVELl, ECONOMIC ANALYSIS OF ACCIDENT LAW 5-32 (1987) (discussing a model for liability and deterrence that includes both injurers and victims). 
on criminals and its ability to induce criminals to select certain victims over others. Such an influence depends upon the access criminals have to the information concerning the relevant behavior of potential victims. Thus, if the legislature wishes to induce certain behaviors on the part of potential victims by differentiating the sanctions imposed upon criminals in accordance with the behavior of their victims, it can do so effectively only if criminals have information concerning the behavior of the victims. But while it is likely that, during their pre-crime activities, criminals obtain information concerning the precautions taken by their victims, it is less likely that they will have information concerning their victim's other virtues or vices. A criminal can observe whether his victim installed locks and alarms, but not whether his victim paid her school loans promptly, contributed to charity, or treated her neighbors respectfully.

Nevertheless, one has to concede that even if criminals could observe whether their victims paid debts or contributed to charity, it may be unjustifiable to differentiate the sanctions imposed upon criminals on the basis of such behavior by victims. Victims' investment in precautions against crime is a natural component of the social costs of crime and, thus, it is naturally a normative target for criminal law. Put differently, both precautions and sanctions are aimed at deterring crime and, thus, designing a scheme that conditions one on the other seems a natural method for implementing optimal deterrence.

\section{c. Criminal Law Versus Fiscal Policy}

Even if it is morally legitimate to use the criminal law to provide incentives for potential victims to invest efficiently in precautions, such incentives could also be provided through other fiscal measures, such as taxation and subsidization of precautionary activity. ${ }^{104}$ Should society use direct fiscal measures or should it use the criminal law to influence victims' behavior?

A full comparison of the advantages of these two implementation methods is beyond the scope of this Article. ${ }^{105}$ It may be that

${ }^{104}$ See Ben-Shahar \& Harel, supra note 6, at 444 (discussing the use of alternative methods to induce victims to invest in the optimal level of private enforcement). We are grateful to Scott Altman and Eric Talley for discussion of this issue.

${ }^{105}$ Some general analytical guidelines are provided in Steven Shavell, The Optimal Structure of Law Enforcement, 36 J.L. \& ECON. 255, 257-61 (1993) (comparing the principal dimensions of law enforcement including tort law, criminal law and safety 
taxing or subsidizing precautions may, under certain circumstances, be superior. It is worthwhile, however, to specify at least one advantage of the system proposed here over direct tax or subsidy. Many of the precautions used by potential victims are simply not taxable. A decision to go or not to go to the cinema, to walk or not to walk in the park, to provoke or not to provoke a potential aggressor, or to lock or not to lock one's car is not the type of decision that can easily be controlled through taxation. Hence, using taxes or subsidies are practical means to guarantee efficient investment in precautions only when precautions are a quantifiable consumption product, that is, traded in a market. Since many of the precautions used by potential victims cannot be taxed, the criminal law mechanism that this Article examines becomes necessary as a means of control.

\section{CONCLUSION}

This Article develops two main themes, one positive and one normative. Under the positive theme, the manner in which precrime activities are treated in the criminal law influences the way criminals select their victims. Consequently, it influences the investment of potential victims in precautions. This positive theme was derived under standard economic assumptions, that is, the assumptions of rationality and foresight on the part of perpetrators and potential victims of crime.

The understanding of the positive theme can help construct various normative arguments. The main normative theme advanced by this Article is that the lenient treatment of pre-crime activities promotes efficiency because it leads to an overall reduction of the investment of potential victims in precautions. This claim depends, however, upon the conjecture that, in the absence of special treatment of pre-crime activities, potential victims will overinvest in precautions. The diversity of conflicting factors that distorts victims' investments in precautions makes the normative claim more speculative. The law of pre-crime activities could be justified on efficiency grounds only if the distortions that motivate victims to overinvest are more powerful than the distortions that motivate victims to underinvest. However, other normative themes may rise from the analysis. The treatment of pre-crime activities can become an instrument to effectuate victims' behavior, no matter what the

regulations). 
underlying objective. A society that wishes to control and monitor the way in which victims behave for reasons outside the scope of efficiency is now equipped with one more weapon in its arsenal.

The victim-centered perspective that this Article advances can be extended in various directions. One theme for future research could be the comparison of the theoretical framework with an empirical verification. By comparing the different observed patterns of behavior of potential victims across jurisdictions that treat pre-crime activities differently, one could verify (or refute) the positive predictions of this Article. Or, alternatively, by examining the changes in the patterns of behavior of potential victims resulting from changes in the legal treatment of pre-crime activities, one could provide an empirical test for the theoretical predictions.

Another theme for possible extension is to apply the victimcentered approach to other areas of criminal law. Are there common practices which are ordinarily justified with respect to their effect on criminals, and which can now be understood with respect to their effect on victims? Lastly, the victim-centered perspective can be extended within its theoretical apparatus if examined under less restrictive informational assumptions. One may inquire, for example, whether victims can be induced to take optimal precautionary measures even when these measures are not readily observable by criminals or courts.

One cannot conclude without the standard proviso that characterizes economic analysis of law. This Article proposes an insight, not a reform. It seeks to understand the effects of different legal regimes, not to design a new one. The reader may elect to reject the normative premise underlying the analysis, as well as its moral implications. In such a case, the Article contributes an understanding of the price of these moral considerations. If society is reluctant to use the criminal law as a means of influencing the behavior of potential victims, it needs to be informed of some important, yet less obvious, ensuing costs. 
HeinOnline -- 145 U. Pa. L. Rev. 352 1996-1997 